\title{
OSMANLI TOPLUM HAYATINDAN BEYITLERE YANSIYAN BİRKAÇ ÖRNEK
}

\section{Murat KEKLIK *}

\begin{abstract}
ÖZ
Yüzyılların birikimiyle şekillenen belirli bir sanat anlayışı içerisinde kesin kuralları çerçevelenmiş, aşinası olmayanlarca kapalı bir kutu olarak addedilen klasik Türk şiiri beyitleri, toplum hayatıyla ilgili pek çok malumatı da ihtiva etmektedir. Bu malumatlar âdet ve gelenekler, inanışlar, ticarî ve askerî hayat, günlük hayatta kullanılan kimi eşyalar, doğa sahneleri, tasavvufî gelenek gibi akla gelebilecek her türlü unsur ile ilgili olabilmektedir. Beyitlerdeki sosyal hayat unsurlarının tespitinde kimi zaman elimizdeki sözlükler yetersiz kalabilmektedir. Beyitlerde geçen günlük hayat veya sosyal yaşama dair kimi kavramların anlaşılması için sözlükler dışında başka kaynaklara müracaat etmek gerekmektedir. Bu kaynaklar arasında klasik Türk edebiyatı araştırmaları çerçevesinde yapılan metin şerhi, metin tahlili çalışmaları, beyitlerdeki kavram ve terimlerin açıklamalarını da içermesi bakımından oldukça önemlidir. Son yıllarda klasik Türk şiirinin toplum hayatıyla ilgisi üzerine hazırlanmış çalışmalarda da sosyal hayata ilişkin kavram, terim ve tabirler üzerine bilgiler verilmektedir. Çalışmamızda da toplum hayatının çeşitli alanlarına dair detay niteliğindeki kavram ve terimler geniş bir yelpazede seçilen beyitler çerçevesinde açıklanmıştır. Klasik Türk edebiyatı şairlerinin çevrelerini ne kadar iyi gözlemledikleri; duygu, düşünce ve hayallerini ifade ederken, söz hünerlerini sergilerken yaptıkları gözlemlerden ne derece istifade ettiklerinin gösterilmesi amaçlanmıştır.
\end{abstract}

Anahtar Kelimeler: Klasik Türk şiiri, divan, beyit, günlük hayat, toplum hayatı

\section{SOME EXAMPLES REFLECTING FROM COUPLETS IN OTTOMAN'S SOCIAL LIFE}

\begin{abstract}
The classical Turkish poetry couplets, which have been formed out of the accumulations of centuries framed by the precise principles of a certain art and aesthetic perception and attributed as "a closed book" who are unfamiliar with them, are embedded with lots of daily features. These features can be about such attributes as conventions, belief, business life, some objects utilized in daily life, sceneries of nature and conventions of tasawwuf and of any features that may recur to mind. In the determination of the social life features in the couplets, the dictionaries under hand may at times prove to be insufficient. It is necessary to consult to sources other than dictionaries to understand some of the terms particularly belonging to daily life or social life. Among these sources, text annotations made within the frame of classical Turkish literature researches, studies of text analyses are considerably significant since they also include the meaning of concepts and terms in the couplets. Moreover, in the studies, which have been recently prepared about the effect of classical Turkish poetry on social
\end{abstract}

\footnotetext{
* Yrd. Doç. Dr., Iğdır Üniversitesi Fen-Edebiyat Fakültesi, Türk Dili ve Edebiyatı Bölümü, m.keklikk@hotmail.com.
} 
life, concepts, terms and expression about social life are explained. In the study, too, concepts and terms, which are in the sense of details from the scenery of social life are tried to be explained in the context of couplets chosen from a wide variety of collection. By way of the study, it is also aimed to demonstrate how well classical Turkish poets observe their environments and to what degree they are benefitting from their observations while expressing their feelings, thoughts and imaginations and displaying their skills.

Keywords: Classical Turkish Poetry, divan/collected poems, couplets, daily life, community life

\section{Giriş}

Destan devirlerinden günümüze kadar, insanın yöneldiği her şey sanata, dolayısıyla edebiyata, şiire konu olmuş ve eserlere yansımıştır. Bu bakımdan edebiyat eserleri insanların yaşadığı devirleri, kurdukları medeniyetleri, hayata bakışlarını anlamada bize çok önemli ipuçları veren, hareket noktaları sağlayan malzemelerle doludur. ${ }^{1}$ Edebî eserler ne kadar donuk, soyut, şekilci, muayyen ve sabit görünüşlü olsa da yaşayan, duyan, gören insanın şahsi çabasının ürünleridirler. Kaidelerin ve başka vasıfların, hayat ve realite ile eserin ilgisini tamamen kesebileceği ve onlardaki bütün gerçekçi izleri silebileceği düşünülemez. Dolayısıyla katı ve değişmez gözüken kabuk ve şeklin altında derece derece insanın ferdî ve sosyal hayatına dair renkli, ilginç, aydınlatıcı detaylar bulunabileceği hatırdan çıkarılmamalıdır. ${ }^{2}$

Diğer bütün edebi eserlerde olduğu gibi klasik Türk şiiri kalıpları içerisinde yazılmış her şiirin de Osmanlı toplum hayatıyla sıkı sıkıya bağlantısı vardır. Yaşadıkları doğal ve sosyal çevreden bağımsız düşünülemeyecek klasik Türk şairleri eserlerini oluştururken yaşadıkları doğal çevrenin, mensubu bulundukları toplumun, içinde yetiştikleri geleneğin tesiri altında kalarak eserlerini kaleme almışlardır. Bu itibarla klasik Türk şiirinin gerektirdiği kalıplar içinde yazılmış her şiirin yaşanılan çevre, gündelik hayat, tarihî malumat, âdet ve gelenekler ile doğrudan veya dolaylı bir ilgisi vardır. Birer sosyal kişilik olarak klasik Türk şairlerinin ortaya koydukları eserlerin tamamıyla hayal mahsulü olduğunu, hayattan kopuk olduğunu söylemek eşyanın tabiatına aykırı olacaktır. ${ }^{3}$

Türk tarih ve medeniyetinin önemli ve büyük bir parçası olan klasik Türk edebiyatı Türkçenin ve Türk sosyal hayatının bütün inceliklerini yansıtır. Beyitlerde ruh dünyamızı, hayatımızı zenginleştirebileceğimiz, okumaktan zevk alacağımız duygu ve düşüncelerimize tercüman olacak pek çok büyülü ve sanatkârane ifadeyle karşılaşılabileceği gibi beyitleri anlamakta gösterilecek gayretle sanatçıya ilham veren gündelik hayatın gözden kaçan pek çok detayının farkına varılabilecektir. Klasik Türk şiirinin günlük yaşayış ve sosyal hayatla ilişkisi konusunda Cem Dilçin, "Divan şiiri, kapsadı̆̆ı uzun zaman dilimi dikkate alındığında, Türk kültürü açısından çok zengin bir kaynak oluşturmaktadır. Durum böyle olduğu hâlde divan

\footnotetext{
Nejat Birinci, Edebiyat Üzerine İncelemeler, Kitabevi, İstanbul, 2000, s. 386.

2 Abdulkadir Karahan, Eski Türk Edebiyatı İncelemeleri, İstanbul Üniversitesi Edebiyat Fakültesi Yay., İstanbul, 1980, s. 57.

3 Mustafa Nejat Sefercioğlu (2002), "Divan Şiirinin Gerçek Hayatla Bağlantısı”, Türkler Ansiklopedisi, Yeni Türkiye Yay. C.11, Ankara, s. 664; M. Nur Doğan, Eski Şiirin Bahçesinde, Alternatif Yay. İstanbul, 2005, s. 46-48.
} 
şiirini, toplum hayatından uzak soyut bir şiir gibi değerlendirmek ve onu özellikle bu açıdan eleştirmek gerçeği tam olarak yansitmamaktadır. Divan şiirinin çok yoğun mecazî dünyası dikkatle incelendiğinde, gerçek hayatın pek çok yönüne ilişkin bilgiler elde edilebilmektedir." demektedir. ${ }^{4}$ Aynı konuda Atillâ Şentürk şöyle der: "Eski edebî metinlerimiz pek az millete nasip olacak derecede zengin ve henüz işlenmemiş binlerce konuyu içinde barındırmaktadır. Bu metinlerin titizlikle tahlili ve birbirleriyle karşılaştırılması sonucu ortaya çıkan eski kültür, hayat tarzı ve malzemelerle ilgili ipuçları bazı hâllerde başka kaynaklara ihtiyaç bırakmayacak derecede zengin bilgi sergileyebilir.” Bu düşüncesine ek olarak Şentürk, “Âdet, usul ve gelenekler, günlük hayatta kullanılan âletler, malzemeler, inançlar vb. her husus o günkü şekilleri ve kullanılış biçimleriyle ele alınıp değerlendirilmezse, metinler lâyıkıla anlaşılmaz. ",5 der. Andrews, Batılıların ve bir kısım Türk aydınlarının Osmanlı şiirinin özellikle gazellerin soyutluğu, kapalılığı yönündeki eleştirilerini haksız ve yersiz bularak yapılan eleştirilerin kuşku uyandırdığını söyler. Ona göre okumuşlar eliti tarafından üretilen yüksek kültüre ait Osmanlı şiirinde sade ve anlaşılır unsurlar kapalı unsurlardan daha fazladır. Araştırmacı kanıtların 1şı̆̆ında ulaştığı sonuçları da şöyle ifade eder: "Osmanlı divan şiirinin, yaklaşık beş yüzyll boyunca serpilip gelişmesine kaynaklık eden başlıca şey, bu şiirin geniş bir kitlenin ilgilendiği önemli konuları akıcı, anlaml ve dolaysız bir biçimde dile getirmiş olmasıdır. "Gerçek" hayatla hiçbir ilgisi olmamak şöyle dursun, çok büyük bir ihtimalle, kendisini üreten kültürün ve toplumun hayatıyla her türlü alışverişi vardır."6 Muhammet Nur Doğan, "Tarih ve gündelik hayat bilgisi Osmanlı şiirini doğru anlamada vazgeçilmez olduğu gibi Osmanlı şiiri de tarih ve günlük hayat hakkında vazgeçilmezdir." "Divan şiirinin toplumdan kopuk olması ne demektir? Sormalı: Hangi yazınsal yapıt yaşamın kendisidir? Divan şiirinin yaşamdan kopuk olduğunu ileri sürenler, kuşkusuz yazın'la yaşam arasında dolayımsız bir bağlantı var saylyorlar. Gene sormalı: acaba bu bağlantıların dolayıml olabileceğini düşünmediler mi? Belki sorunu bu düzlemde alırsak divan şiirinin gerçek yaşamla bağlantılarını yüzeyde değil, ama derin yapıda ortaya koyabiliriz.(...) Anlaşılır gibi değil: hem yaşamla ilgisi az olacak hem de kendi döneminin bütün izlerini taşıyacak! Yazın'ın yaşamın kendisi olmadığl, olamayacă̆ şöyle dursun (yazınsal yapıt, kurmaca'dır çünkü), bir yazın çağına tanıklık ediyorsa, onun yaşamla ilişkili olmadığı nasıl söylenebilir?" " N. Sami Banarlı da halk ve klasik Türk şiirine bakışın değişmesi hususunu dile getirirken gençlere şöyle seslenir: "Türk Halk Edebiyatında, Türk Divan Edebiyatında göreceğiniz sosyal, tarihi, fikri ve estetik çizgilere nüfuz ediniz. Eski Türkler, uzun söylemez, fakat derin söyler, veciz söyler, çok kere sahifelerce söylenecek bir sözü, bir beyitte, bir dörtlükte söylemenin sırrına ererlerdi. Bu arada, millî, içtimaî ve beşerî olan her mevzua, her duygu, düşünceye mutlaka temas eder, söyleyince de çok güzel söylerdiler. Bu edebiyata,

4 Cem Dilçin,“Türk Kültürü Kaynağı Olarak Divan Şiiri”, Türk Dili, S. 571, 1999, s. 618.

5 Atillâ Şentürk, "Klâsik Osmanlı Edebiyatı Işı̆̆ında Eski Âdetler ve Günlük Hayattan Sahneler", Türk Dili, S. 495, 1993, s. 175, 178.

6 Walter G. Andrews, Şiirin Sesi, Toplumun Şarkısı, (çev. Tansel Güney), İletişim Yayınları, İstanbul, 2012, s. 32 .

7 M. Nur Doğan, age. s. 49.

8 Hilmi Yavuz, "Divan Şiiri, Simgeci Bir Şiir mi?”, Osmanlı Divan Şiiri Üzerine Metinler, (Haz. Mehmet Kalpakl1), YKY, İstanbul, 1999, s. 261. 
çeşitli sebeplerle, bir asırdan beri yapılan iftiralara aldanmayınız. Ona her türlü ard düşüncenin üstünde, gerçekçi ve ilimci bakışlarla bakınız. "9

Klasik Türk şiiri ile Osmanlı toplum hayatı arasındaki ilişkiyi ortaya koyan görüşlere yenilerini eklemek mümkündür. Bu görüşlerin birleştiği nokta klasik Türk şiirinin bir yüksek kültür edebiyatı olmasına karşın hiçbir şekilde hayattan kopuk olmadığıdır. Klasik Türk şiiri çok çeşitli kaynaklardan beslenmektedir. Bu kaynaklar din ve tasavvuf, tarih ve sosyal hayat, ilim ve felsefe, estetik değerler sistemi olarak dört ana başlıkta toplanabilir. ${ }^{10}$ Beyitlerde bu kaynakların birden fazlası bir arada kullanıldığı göz önünde bulundurulacak olursa bunların birbirinden ayrı öğeler hâlinde değil iç içe geçtikleri görülecektir. Klasik Türk şairleri de bu kaynaklardan aldıkları ilhamları gelenek icabı ince, zarif ve aynı zamanda kapalı bir şekilde estetize ederek şiir diline dönüştürmüşlerdir. Okurlara düşen görev eserlerin yazıldığı çağın okurunun gözüyle bu eserlere yaklaşmak ve eserlerin yazıldığı çağdaki inanç, dünya görüşü, toplum hayatı, sanat anlayışı hakkında bilgi sahibi olmaya çalışmaktır.

Klasik Türk şiirinde toplum hayatının izleri üzerine kitap, tez, makale, divan tahlili şeklinde yapılan çalışmaların sayısında son yıllarda büyük bir artış gözlemlenmektedir. Fatma Meliha Şen "Eski Türk Edebiyatında Sosyal Hayat Çalışmaları” başlığı altında yayımladığı makalesinde 2007 yılına kadar konu üzerine yapılan çalışmaları kitap, tez, makale başlıklarında sınıflandırarak çalışmaların bibliyografik künyelerini vermiştir. ${ }^{11}$ Söz konusu makalede belirtilen çalışmalara her geçen gün yenileri eklenmektedir. ${ }^{12}$ Ahmet Atillâ Şentürk tarafından hazırlanmakta olan "Osmanlı Şiir Kılavuzu"13 -henüz ilk iki cildi tamamlanarak yayınlanmasına karşın- ihtiva ettiği madde sayısıyla, yüzlerce divandan alınan beyit örnekleri ışığında maddelere yapılan izahlarıyla Osmanlı şiirinde toplum hayatını konu alan çalışmalara da kaynaklık edecektir.

Klasik Türk edebiyatındaki sosyal hayat çalışmalarında çok farklı yaklaşımlar söz konusudur. Çalışmalarda çoğunlukla belli bir eserden seçilen sosyal hayat alanı üzerinden muhteva incelemeleri yapılmaktadır. Bu tip çalışmalarda çalışmaya konu olan eserde özellik arz eden âdet ve gelenekler, halk inanışları, musiki, kılıkkıyafet, atasözü ve deyimler gibi sosyal hayat alanlarından biri ele alınmaktadır. Diğer taraftan bazı çalışmalarda belli bir yüzyılda öne çıkan şairlerin divanlarındaki sosyal hayat unsurları ana ve alt başlıklar şeklinde tasnif edilerek incelenmiştir. Kimi çalışmalarda da belirlenen sosyal hayat unsurlarıyla ilgili değişik eserlerden örnekler verilerek açıklamalar yapılmaktadır. Bu çalışma da son türden çalışmalar arasında yer almakta olup çalışmada Osmanlı toplum hayatının farklı alanlarından örnekler

\footnotetext{
9 Nihad Sami Banarlı, Şiir ve Edebiyat Sohbetleri 2, Kubbealtı, İstanbul, 1982, s. 12.

10 M. Nur Doğan, age. s.13.

${ }^{11}$ Fatma Meliha Şen, "Eski Türk Edebiyatında Sosyal Hayat Çalışmaları" Türkiye Araştırmaları Literatür Dergisi, C. 5, S. 9, 2007, s. 467-506.

12 2007'den sonra yapılan çalışmalardan bazıları: Hasan Kaya, “Azmizâde Hâletî Divanı'nda Âdet ve Gelenekler", Divan Edebiyatı Araştırmaları Dergisi, S. 5, 2010, s. 133-183; Ömer Savran, "Klâsik Şiirimizde Ölüm Teması ve Ölümle İlgili Bazı Âdetler”, Sosyal Araştırmalar Dergisi, S. 2, 2009, s. 170-187; Hasan Kaya, 18. yy. Şairi Âsaf ve Divanı, (Marmara Üniversitesi Türkiyat Araştırmaları Enstitüsü, Yayımlanmamış Doktora Tezi), İstanbul, 2009, s. 189-218; Hakan Yekbaş, "Zâtî Dîvanında Halk İnanışları”, Turkish Studies, Volume 4/2 Winter 2009, s. 1085-1125; H. İbrahim Demirkazık, "Emrî Divanı'nda Âdet ve Gelenekler", Divan Edebiyatı Araştırmaları Dergisi, S. 9, İstanbul 2012, 49-110; Neslihan Koç Keskin, Sosyal Hayatın 17.yy. Divan Şiirine Yansımaları ve Anlam Çerçeveleri, (GÜSBE Basılmamış Doktora Tezi), Ankara, 2009.

13 Ahmet Atillâ Şentürk, Osmanlı Şiir Kılavuzu I, II, OSEDAM, İstanbul, 2016.
} 
seçilmiştir. Böylesi bir yolun takip edilmesinde, geniş bir zaman diliminde ve geniş bir coğrafyada şiirler kaleme alan klasik Türk şairlerinin duygu, düşünce ve maksatlarını ifade etmek için mensubu oldukları toplumun günlük hayatlarını ne kadar yakından gözlemlediklerinin gösterilmesi amaçlanmıştır. Aşağıda ele alınan toplum hayatına dair konu maddeleri doktora çalışmamıza konu olan Üsküplü İshak Çelebi Divanı'nın ${ }^{14}$ taranmasıyla belirlenmiştir. İlgili konu maddelerinin çoğuna tez çalışmasında kısaca değinilmiştir. Bu çalışmada ise konu maddeleriyle ilgili beyit örnekleri çoğaltılmış, beyitlerin nesre çevirisi yapılmış, beyitlerden ve müracaat edilen kaynaklardan hareketle konu maddeleri açıklanmıştır. Örnek beyitlerin imlâlarına müdahale edilmemiş, her beytin sonunda alındıkları kaynaktaki şiir ve beyit numarası verilmiştir.

\section{Osmanlı Toplum Hayatından Beyitlere Yansıyan Örnekler}

'ankebût-peşşe: Arapça bir isim olan ankebût'un Türkçe karş1lığ1 örümcek; Farsça bir isim olan peşşe'nin Türkçe karşılığı ise sivrisinektir. ${ }^{15}$ Klasik Türk şiirinde örümcek ile sivrisineği bir araya getiren ise bir doğa olayıdır. Doğal hayat ve sosyal çevrede sivrisineklerin takılıp kaldığı örümcek ağlarına sıkça rastlanmaktadır. Örümcekler özellikle de sineklerin çokça uçuştuğu lamba gibi aydınlatma araçlarının bulunduğu yerlere ağlarını örer sonra da avlarını beklemek üzere saklanırlar. Sinek ve sivrisineklerin ağlara yakalanması gibi bir doğa olayı yeni imajlar için şairlere her zaman ilham kaynağı olmuştur.

Gitdi görünmez oldl yine 'ankebût-ı mihr

Çün zâhir oldı peşşe gibi bî-şümâr berf

(İshak Çelebi, k. 9/4)

"Güneş örümceği gitti, yine görünmez oldu. Çünkü sivrisinek gibi sayısız kar taneciği ortaya çıktı.”

Beyitte kar yağarken güneşin kaybolması gibi bir tabiat olayı yine tabiatta karşılaşılan bir olay olan sinekleri gören örümceğin ortadan kaybolmasına benzetilmiştir. Şair beyitte güneş örümceğinin ortadan kaybolmasının nedenini sayısız sivrisinek gibi kar tanelerinin ortaya çıkmasına bağlamıştır. Güneş de yağan karın ardından saklandığı yerden çıkan örümcek gibi ortaya çıkacak ve hükmünü yerdeki kara gösterecektir.

Kîl u kâl-i 'akla dolaşdı dil-i zâhid yine

'Ankebûtun târına düşdi sanasan bir zübâb

"Zahidin gönlü yine aklın boş sözlerine takılıp kaldı; zannedersin bir sinek örümceğin ağına takıldı."

Târ-ı ankebût gibi sarmış aceb deryâ seni

Bizlere sen viz viz itme bezm evinden meges

(Ferhad Paşa, g. 39/3)

"Sinek (zahid)! Farklı bir derya örümcek ağı gibi seni sarmalamış; meclisimizde bizlere viz viz edip durma."

\footnotetext{
${ }_{14}$ Murat Keklik, Üsküplü İshak Çelebi: Divan [Metin-Çeviri-Açıklamalar-Dizin], Kırgızistan-Türkiye Manas Üniversitesi, Sosyal Bilimler Enstitüsü, Yayımlanmamış Doktora Tezi), Bişkek, 2014.

${ }^{15}$ Şemseddin Sami, Kāmûs-i Türk̂̂, Kapı Yayınları, İstanbul, 2004, s. 356, 954.
} 
Dehr-i pîç-â-piçe dil veren eger 'Ankā ise

Şol megesdür kim giriftâr etdi dâm-l 'ankebût

(Aşkî, g. 21/2)

"Karmakarışık dünyaya gönül veren Anka da olsa; örümcek ağına yakalanmış bir sinek gibidir."

Aşağıdaki beyitte de şair bir örümcek ağ1 ve ona yakalanmış bir sinek hayalinden hareket etmektedir. İyice zayıflamış, kanı çekilmiş olan göz damarlarını örümcek ağına, sevgilinin siyah benlerini ise o ağa takılmış ve örümceğe yem olmuş sineklere benzetmektedir;

Merdüm-i çeşmümle her reg oldı târ-ı 'ankebût

'Aks-i hâlün bir meges gibidür olmış ana kût

(Bursalı Rahmî, g. 16/1)

"Gözlerimdeki damarlar gözbebeklerimin çevresindeki örümcek ağına benzedi; zannedersin ki beninin yansıması da ona gıda olmuş bir sinektir."

'atıyye: "Atâ" Arapçada mastar durumunda bir kelimedir. "Verme, cömertçe verme, verilen şey, bağışlama, hibe, ihsan' demektir. Atâ et-/kll- ise hediye etmek, ihsan etmek, bağışlamak, hibe etmek anlamlarına gelir. ${ }^{16}$ Mertol Tulum "atâ" maddesi altında kelimenin bağışlayış, veriş, vergi, iyilik, in 'am, ihsan, kerem, bahşiş, armăgan, ber-güzâr, hediye, müjde, tuhfe, pîşkeş ${ }^{17}$ gibi anlamlarını vermektedir. Atâ'ile aynı kökten olan "atıyye" hediye, ihsan, bahşiş, bir büyüğün küçüğe verdiği hediye demektir. Atıyye'nin çoğulu atâyâ'dır. Atâ Kur'ân-ı Kerîm'de, 'nimet, lutuf, ihsan ve bağış' anlamlarında beş yerde geçmektedir (Hûd 11/108; el-İsrâ 17/ 20 [iki defa]; Sâd 38/39; en-Nebe' 78/36). Hz. Ömer'in kurduğu divan teşkilatında feyden Müslümanlara yılda bir defa dağıtılan paraya, Emevi ve Abbasiler zamanında ise askerlerin maaşlarına atıyye denilmiştir. ${ }^{18}$

Osmanlı döneminde padişahlar muhtelif vesilelerle saray ve hükûmet hizmetinde bulunanlara hediye ve bahşiş amaçlı atıyye vermişlerdir. Bu hediyelere ise atiyye-i seniyye denmiştir. Atıyye olarak para verildiği gibi, kılıç, saat, enfiye kutusu da verilmiştir. ${ }^{19}$ Beyitlerdeki kullanımlarından anlaşıldığı kadarıyla hediye anlamını da ihtiva etmekle birlikte atıyyenin hediyeden farkı, hediye herkese özellikle sevilenlere verilirken atıyye'nin muhtaçlara, düşkünlere veya bir hizmet karşılığı verilmesidir. Atıyye büyüğün küçüğe bir nevi ihsanıdır. Klasik Türk şiirinde âşıklar sevgiliden gelen her türlü iyiliği atıyye olarak görmüşlerdir;

Nev'îye geçerken güle bakdı seg-i kûyun

El-minnetü li'llâh zihî lutf $u$ 'atiyye

(Nev'’̂, g. 388/5)

“Semtinin köpekleri geçerken Nev'̂̂’ye gülerek baktı. Minnet Allah'a! Bu ne güzel lütuf ve hediye!"

\footnotetext{
${ }_{16}$ Andreas Tietze, Tarihi ve Etimolojik Türkiye Türkçesi Lugatı, C I, Simurg, İstanbul-Wien, 2002, s. 223.

${ }_{17}$ Mertol Tulum, 17. Yüzyıl Türkçesi ve Söz Varliğı, TDK Yay., Ankara, 2011, s.341.

${ }_{18}$ Mustafa Fayda, "Atâ". TDVİA, C. 4, İstanbul, s. 33.

19 M. Zeki Pakalın, Osmanlı Tarih Deyimleri ve Terimleri Sözlüğü, C. I, MEB Yayınları, İstanbul, 2004, s. 110 .
} 
Bîmâr-ı haste-hâtıra sohbet ne fâyide

Olmaylcak 'atıyye-i sihhat ne fâyide

(İshak Çelebi, g. 278/1)

"Gönlü yaralı hastaya sohbet fayda vermez; s1hhat lutfedilmedikten sonra yapılacak bir şey yok."

'Atiyyedür sana hâsiyyet-i veliyyu'llâh

Seni sitâyiş idenler dahi olur mehcûr

(Pertev, k. 3/21)

"Velilerin hasletleri sana verilmiştir; seni övmeye kalkanlar dahi hüsrana uğrar."

akça saçmak: İslâmiyet öncesi devirlerden günümüze kadar Türk dünyasında bütün canlılığıyla uygulanagelen geleneklerden birisi de saçı geleneğidir. Bu geleneğe göre dügüülerde gelinin başına, kılıç kuşanma gibi törenlerde sultanların ayağına, sevinçli bir haber alındığında, türlü vesilelerle yapılan kutlamalarda vs. para veya değerli şeyler saçılırdı. ${ }^{20}$ Saçı saçma geleneği içerisinde değerlendirilebilecek uygulamalardan birisi de gelişi sevinçle karşılanan bir büyüğün, kişinin yoluna veya ayaklarına akça saçılmasıdır. Klasik Türk şairleri tabiat olaylarıyla bu köklü Türk geleneği arasında benzerlik ilgisi kurmuş, âşığın gözyaşlarını yeri geldiğinde saçıya benzetmişlerdir.

Nevruz'un hemen öncesinde yağan kar, baharı karşılamak için saçılan gümüş akçelere benzetilir;

Nevrûza karşı saçdı felek berf-i bî-şümâr

Lâyıdur akça saçmaga hakkâ ki nevbahâr

(Nev'̂̂, k. 26/1)

“Gökyüzü Nevruz’u karşılamak için hadsiz hesapsız kar döktü; hakkını yemeyelim ilkbahar yoluna akçe saçılmaya layıktır."

Çimenlikte açılan yaseminler baharın gelişi için yerlere saçılan akçelerdir. Yaseminler çoğunlukla beyaz renkte açan çiçeklerdir. Şair tevriye yaparken $a k c ̧ a$ kelimesinin hem gümüş para hem de beyaz anlamlarından yararlanmıştır.

Makdemünden ki gülistâna haber verdi nesîm

Yâsemen ayagına akçasını etdi nisâr

(İshak Çelebi, g. 83/8)

"Meltem, gül bahçesine gelişinin haberini verdi; yasemin akçelerini yoluna saçtı."

Eşcâr aldı eline ezhâr akçesin

Kıldı bu şâh ayagına elvân nisârı gör

(Günehkâr, g. 16/11)

"Ağaçlar ellerine çiçek akçelerini alarak fidanların ayaklarına döktüler; envai çeşit saçılmışları gör."

Sevgili için âşığın döktüğü gözyaşları da akçeye benzetilir;

Eşk-i Emrî gece akça saçdı ol mâh üstine

Sanma encüm dâmenün toldurdı akçayla felek

(Emrî, mk. 275/1)

${ }^{20}$ Orhan Kurtoğlu, "Klasik Türk Şiirinde Saçı Geleneği”, Millî Folklor, S. 81, 2009, s. 88-99. 
“(Gökyüzündekileri) yıldız zannetme! Emrî’nin gözyaşları o ay üzerine gece akçe saçtt; gökyüzü eteğini akçelerle doldurdu."

Yoluna dökmeden aglarsa eşki akçasını

Agardı aglamadan gözleri bu giryânun

(Emrî, g.285/1)

"Gözyaşı akçasını yoluna dökmeden ağlarsa; bu ağlağın ağlamaktan gözlerine perde iner."

halka-be-gûș: 'Kulağına halka takılı' demek olup köle ve hizmetlileri ifade etmek için kullanılan bir tabirdir. Daha çok Farslarda görülen bir âdet olmakla birlikte Osmanlıda da diğer hizmetli, yanaşma ve uşaklardan (yumuş oğlanı, der oğlanı, rehî) ayırt etmek için satın alınmış kölelerin kulaklarına halka takılırdı. ${ }^{21} \mathrm{Bu}$ âdetin bir benzeri Bektaşîlerde de vardır. Bektaşî babaları Şâh-1 Velâyet ve Hacı Bektaş'ın kölesi olduklarını göstermek için mengûş adı verilen halkaları kulaklarına takarlardı. Bu halkayı takan Bektaşî dervişleri ölünceye kadar bekâr yaşarlardı. Hayderî, Şemsî, Camî, Edhemî mensuplarıyla mücerred kalenderler (evlenmeyen dervişler) de halka takarlardı. "Manzum Metinler Işı ğında Bir Kalender Dervişinin Profili”" adlı makalesinde A. Atillâ Şentürk gezginci bâtınî dervişlerin görünüş ve davranışları hakkında detaylı bilgiler vermiş, beyitlerde kalender dervişler üzerinden oluşturulan imaj ve imgeleri tespit etmiş, açıklamalarda bulunmuştur. Araştırmada en bariz özellikleri kulaklarına taktıkları hilâl, kapı halkası, at nalı şeklindeki küpeler olan Kalenderî ve Hayderî dervişlerinin kulaklarındaki takılarla kulluklarını, tarikat pirlerine bağlılıklarını göstermeyi amaçladıkları belirtilmiştir. ${ }^{22}$ Kulağa halka takmanın ifade ettiği anlam ve halkaları takanların özellikleri göz önünde bulundurularak tabirin geçtiği beyitler yorumlandığında halka-be-guşs tabirinin özellikle azatlı̆̆ 1 kabul etmeyen köleler ile esirleri ifade etmek için şiirlerde kullanıldığı anlaşılmaktadır. Aşağıdaki beyitlerde de şairler âşığın sevgiliye duyduğu bağlılığ 1 , iştiyakı, sevgilinin erişilmezliğini halka-begîş tabirinden hareketle oluşturdukları imajlarla dile getirmişlerdir;

Bir şehsüvâra halka-be-gûşam ki atınun

Her bir nişân-ı na'li birer secde-gâh imiş

(Hayretî, g. 162/4)

“(Öyle) bir süvarinin kulağı halkalı kölesiyim ki atının nalının her bir izi birer secde yeridir."

Mâh-ı nev halka-be-gûş-ı der-i sultân-ı sehâ

Şems zer tâc ile derbân-ı cihânbân-ı kerem

(Aşkî, k. m. 21-a/5)

"Yeni ay, cömertlik sultanının kapısında kulağı halkalı bir köledir. Güneş ise altın tacıyla o yücelikler padişahının kapıcısıdır."

Bende-i halka-be-gûş oldı varup hıdmetüne

Devleti kendüye kul eylemek ister hâtem

(İshak Çelebi, k. 6/5)

\footnotetext{
${ }^{21}$ Ozan Yilmaz, 16. Yüzyll Şârihlerinden Sûd̂̀-i Bosnevî ve Şerh-i Gülistân'ı, (Marmara Üniversitesi Türkiyat Araştırmaları Enstitüsü, Doktora Tezi), İstanbul, 2008, s. 440.

${ }^{22}$ Ahmet Atillâ Şentürk, "Manzum Metinler Işı̆̆ıında Bir Kalender Dervişinin Profilil", Turkish Studies, Volume 10/8 Spring, 2015, s. 192-193.
} 
"Mühür, devleti kendisine kul etmek istediği için; hizmetine girerek kulağı halkalı bir köle oldu."

Kâmiyâ halka be-gûş eyledi tavk-ı kameri

Bendedür serv dahı nâmıdur âzâd ancak

(Kâmi, g. 117/7)

"Ey Kâmi! Ayın halesini bile kulağı halkalı eyledi; namının "azat” olduğuna bakma servi dahi ona köledir."

Jâleler dürr-i Necef dakdı kulagına anun

Oldı gül halka-be-gûşı o ruh-ı zîbânun

(Emrî, g. 269/2) incisi takt1."

“Gül o güzel yüzlünün kulağına halka olunca; jaleler de onun kulağına Necef

Hayr-hâhın bende-yi halka-be-gûşundur n'ola

Olsa hüsn ü himmetinle kâm-rân u kâm-yâb

(Sabrî, k. 7/29)

"Duacındır, kulağı halkalı kölendir; iyilik ve yardımınla sevinip mutlu olsa ne çıkar."

boyna kement takmak: Eskiden kaplan gibi yırtıcı hayvanların, av hayvanlarının ve suçluların boyunlarına onları zapt etmek veya bir yerden bir yere çekip götürmek için kement takılırd1. ${ }^{23}$ Yine öldürülmek istenen adamın boynuna ilmikli kement takılıp sıkılmak suretiyle canına kıyılırdı. ${ }^{24}$

Aşağıdaki beyit kulağı halkalı köle ile boynu kementli köleyi kıyaslaması açısından kayda değerdir.

Gulâm-ı halka-der-gûş it kapunda tek ten-i zârı

Kemend-i halka-bend-i gamdan âzâd eyle sultânum

(Kabûlî, g. 228/2)

"Sultanım! İştiyak içindeki inleyen cismimi gamın ilmikli kemendinden kurtar, kapında kulağı halkalı köle et."

Eskilerin palâheng adını da verdikleri kemendin aslanların boynuna takıldığ beyitlerden anlaşılmaktadır;

Sayd-gâh-ı 'arşa çıkdukça kemend-i kudretün

Şîr-i gerdûn boynina fi'l-hâl dakar pâleheng

"Senin kudretinin kemendi arşın avlağına çıktıkça felek aslanının boynuna hemen kement takar."

Eskiden kılıç ve hançerleri taşımak için kabzalarına kement bağlanırdı. Şair bu uygulamadan hareketle aşağıdaki beyitte güzel bir hüsnü ta'lil yapmıştır. Hizmette kusur eden kılıç boynuna kement takarak özür diler. Kendi eliyle boynuna kement takanlar kaderlerine razı gelmiş olurlar;

${ }^{23}$ Esma Şahin, “Klâsik Türk Şiirinde Pâleheng ve Bâkî’nin Pâleheng Konulu Bir Gazeli”, Turkish Studies, Volume 7/3 Summer, Ankara, 2012, s. 2388.

${ }^{24}$ Mehmet Zeki Pakalın, age, C. II, s. 240. 
Sen şehriyâr öninde takup boynına kemend

Taksîr-i hidmet içün eder i'tizâr tîg

(İshak Çelebi, k. 5/7)

"Kılıç, hizmette kusur ettiği için; boynuna kement takarak sen padişahın önünde özür diler."

Klasik Türk şiirinde çok karşılaşılan mazmunlardan biri de sevgilinin saçlarının kemende benzetilmesidir. Sevgili saç kemendini âşığın boynuna dolamış, âşığı boynu bağlı kölesi yapmıştır. Bu kement boynuna dolandığında zahidi bile yolundan döndürecek güce sahiptir;

Zülfün bu benüm boynuma kim dakdı kemendi

Itdi beni bende sana bend ile efendi

(Edirneli Nazmî, g. 6211/1)

"Efendi! Saçların benim bu boynuma kemendini taktı; beni sana bağlı köle etti."

\section{Takup kemend boynuna döndürdü Ka 'beden}

Çekdi çevirdi zâhid-i zerrâkı zülf ü hat

(Nedim, g. 55/7)

“Zülüf ve ayva tüyleri, boynuna kement takarak ikiyüzlü zahidi Kâbe'den döndürdü ve ona çekidüzen verdi."

Eskiden delilerin boyunlarına zincir takıldığını, "deliye bend gerek" şeklinde bir deyimin de bu uygulamadan hareketle dile yerleştiğini aşağıdaki beyitten çıkarabiliriz;

Kemende çek dili pend ü nasîhate çekme

Efendi pend gerekmez delüye bend gerek

(Kabûlî, g. 211/2)

"Efendi! Gönüle tenbih ve nasihati bırak, ona kement vur; deliye zincir gerek, tenbih gerekmez."

benefşe-reyhân: Menekşe duvar kenarlarında, gül fidanının ve diğer çiçeklerin dibinde biter, boynu eğik duruşuyla secdeye varmış bir hâlde tasvir edilir, bazen de başını dizlerinin arasına almış birine benzetilir. ${ }^{25}$ Reyhan ise kokusu, rengi ve eskiden sümbül demetlerinin bağlanmasında kullanıldığı için sevgilinin saçlarıyla birlikte anılır. Menekşe ile reyhan arasındaki ilgi aşağıdaki beyitte bir top menekşe reyhanla bağlanırken görülmektedir. Reyhancı aynı zamanda çiçekçi anlamına da gelmektedir.

Hüsn bâgını temâşâya varan 'uşşâka

Saçı reyhâncısı bir tôp benefşe dikiler

(İshak Çelebi, g. 41/5)

"Güzellik bağını seyretmeye gelen âşıklara reyhancı saçı bir demet menekşe getirir."

Bulunduğu yer ve işlev itibariyle menekşe reyhandan üstündür. Şair, "Benefşe var iken reyhana rağbet olmaz" derken benzetme ilgisi kurarak sevgilinin gül gibi dudakları çevresindeki ayva tüyleri varken saçlara yakın tüylere kim bakar demek ister;

${ }_{25}$ Ömer Zülfe, Şiirin İzinde Sözün Gölgesinde, Bilge Kültür Sanat Yayınları, İstanbul, 2001, s. 23. 
Benefşe var iken reyhâna ragbet olmaz anun'çün

Hat-ı müşkîn olan dilberde zülf-i 'anberîn olmaz

(İshak Çelebi, g. 106/6)

"Menekşe varken reyhana rağbet olmaz; dolayısıyla miskten ayva tüyleri olan güzelde amber kokulu saçlar olmaz."

Erse zülfüne sabâ âb-ı izârın yüzüne

Ter benefşe saçılır sünbül ü reyhân dökülür

(Ahmed Paşa, g. 72/3)

"Rüzgâr saçlarına değse ıslak yanaklı yüzüne taze menekşeler saçılır, reyhan ve sümbüller ise dağılır."

Sevgilinin yanağındaki bene benzetilen menekşenin üzüntüyle boynunu bükmesinin sebebi sevgilinin yanağı üzerinde gördüğü reyhana benzeyen ayva tüyleridir;

Hatt-ı reyhânunı gülşende benefşe göreli

Gussadan başını kaldurmadı mahzûn oldı

(Mesîhî, g. 255/5)

"Menekşe gül bahçesinde reyhana benzeyen ayva tüylerini göreli; üzüntüden başını kaldıramadı, hüzünlendi."

akrep-reyhan: Halk arasında reyhanın akrep zehrine iyi geldiği ve reyhanın olduğu yerlere akrep yaklaşmadığ 1 şeklinde yaygın bir inanış vardır.

Klasik Türk şiirinde saçla ilgili yapılan benzetmeler arasında akrep de bulunmaktadır. Kıskaçları, kuyruğu, siyah rengi, kıvrım kıvrım oluşu sebebiyle akrep saçın benzetilenleri arasındadır. Yüzün iki tarafından sarkan siyah saçlar şekil ve renk açısından akrebi andırır. Bir güzellik unsuru olan âşığı sevgiliye bağlayan saç klasik Türk şiirinde fitne, tuzak, avcı olarak görüldüğünden akrep gibi tehlikelidir, ondan korkulması gerekir. ${ }^{26}$ Sevgilinin saçları akrebe benzetilirken yanaktaki ayva tüyleri de renk ve görünüş itibariyle reyhana benzetilir. Reyhanla akrep bir araya gelemeyeceğinden âşık sevgilinin saçlarıyla ayva tüylerini sarmaş dolaş gördügüünde şaşkınlığını gizleyemez;

Zülfi hattlyla ne yüzden oldı yâ Rab hem-nişîn

Resmidür hod 'akrebün dirler ki reyhândan kaçar

"Ey Allah'ım! Saçları ayva tüyleriyle hangi sebepten ahbap oldu; oysa düsturdur söylenir 'akrebin kendi reyhandan kaçar'."

“r” sesinin hâkim olduğu aşağıdaki beyitte de yukarıdaki beytin tersine sevgilinin saçlarıyla yanaklarındaki tüyler bir türlü bir araya gelemez;

Çün râh-ı reyhânîdürür reyyân-ı ruh olmaz 'aceb

Def' itse darb-l 'akrebi dirler ki reyhân öldürür

(Cafer Çelebi)

"Reyhanlarla dolu bir yer olduğu için yanağın tazeliğine şaşılmamalı; (sevgili) akrebe benzeyen ayva tüylerini uzaklaştırsa reyhan öldürdüğünü/uzaklaştırdığını zannederler."

\footnotetext{
${ }^{26}$ Âmil Çelebioğlu, "Fuzûlî’nin Bir Beyti Üzerinde Bazı Düşünceler”, Osmanlı Araştırmaları VII-VIII, İstanbul, 1988, s. 206.
} 
Gejdüm-i hussâda tûgun perçemi reyhân ola

Devletün gülzârı reşk-i ravza-i Rıdvân ola

(Cafer Çelebi) $)^{27}$

"Akrep gibi hasetçi düşmanlarına tuğunun perçemi reyhan olsun; devletinin gül bahçesi Rıdvan'ın cennet bahçesi tarafından kıskanılsın.”

Meclisteki âşıkları rakibin kötülüklerinden uzak tutmak için şair şuh gözlü sakiden reyhan demetini ister;

Akreb rakîbin şerrini uşşâkdan def'etmege

Ey şûh gözlü şâh-l gül ol hûşe-i reyhânı sun

(Ahmed Paşa, g. 223/5)

"Ey şuh gözlü gül fidanı! Âşıkları akrep gibi rakibin şerrinden (zehrinden) uzak tutmak için ol reyhan destesini sun."

Eskiden içki meclislerinin müdavimleri arasında reyhancılar, buhurcular, bahçıvanlar da bulunurdu. Reyhancılar yetiştirdikleri veya topladıkları çeşit çeşit güzel kokulu çiçekleri eğlence meclislerinde satarlardı. ${ }^{28}$ Klasik Türk şiirinde sevgilinin ayva tüyleri ve saçları reyhancı olarak hayal edilmiştir. Eğlence meclislerinde reyhancıların bulunduğunu aşağıdaki beyitlerden de tespit etmek mümkündür;

Kirpügü cevr okına peykâncı

Zülfü cân meclisinde reyhâncı

(Ahmed Paşa, g. 300/1)

"Kirpiği cevir okuna peykancı; saçları can meclisine reyhancıdır."

Nice bezme oldı reyhancı bu şeb sünbüllerün

Kande açıldı 'aceb ruhsar-l gül-nârun senün

(Zâtî, g. 675/2)

"Sünbüllerin bu gece birçok meclise reyhancı oldu; acaba senin nar çiçeği yanakların nerelerde açıldı?"

Çarsĥ̀-yı dil ü cân içre hatı reyhâncı

Gözi kassâb u leb-i la'li şeker-rîz geçer

(Hayretî, g. 78/4)

“Can ve gönül çarşısında ayva tüyleri reyhancı, gözü kasap, la’l dudakları şekerci olarak bilinir."

bürc-i 'akreb (akrep burcu): Osmanlı toplumunda gündelik hayatla akrep burcu arasında yakın ilgi kurulmuş bu ilgilerden hareketle beyitlerde imaj ve mazmunlar oluşturulmuştur. Akrep burcu sabit halde bulunan yıldız kümesidir ve şekli akrebi andırır. 24 Ekim-21 Kasım tarihleri arası Akrep burcunun tarihleridir. Sonbahar burçlarındandır, elementi su ve gezegeni Merih’tir. Merih uğursuz sayılan gezegenlerdendir. Ay bu burçtayken yapılmasının uğursuz olduğuna inanılan şeyler olmakla birlikte bu durum burcun her gününün uğursuz sayılması anlamına

\footnotetext{
27 Ahmet Atillâ Şentürk, "Klasik Osmanlı Edebiyatında Tipler”, Osmanlı Araştırmaları XV, İstanbul, 1995, s. 87. (Yukarıdaki Cafer Çelebiye ait beyitler bu çalışmadan alınmıştır)

${ }_{28}$ Ömer Özkan, Divan Şiirinin Penceresinden Osmanlı Toplum Hayatı, Kitabevi Yayınları, İstanbul, 2007, s. $77,104$.
} 
gelmemektedir. Ay Akrep burcundayken yazı yazmak, bilimle uğraşmak iyi bilinirken, sefere çıkmak uğursuzluk sayılmıştır. ${ }^{29}$

Klasik Türk şiirinde sevgilinin saçlarının akreple anılmasında kıvrımlı uçlarının ve renginin etkisi vardır. Akrep burcu gibi akrepler de çoğunlukla geceleri görülür. Gece ayın doğması ve sevgilinin yüzünün ay olarak tasavvur edilmesinden hareketle yanaktaki saçlar da akrep olarak değerlendirilir. Sevgilinin saçlarının akrep burcuyla olan ilişkisi ise dönemin astroloji ilmi ile ilgilidir. Astrolojide ayın burçlarla olan ilgisi malumdur. Özellikle akrep burcuyla ay bir araya geldiği zaman kargaşa, savaş ve fitnenin arttığına inanılır. ${ }^{30}$ Akrep (Kejdüm) burcunun uğursuzluğuna inanılır, onun devrinde fitne çoktur. Ay akrep burcundayken kötülüklerden sakınmak gerekir. Yağmur, yalan, savaş, sıkıntı, üzüntü artar ve yayılır; ayrıca yolculuğa çıkmanın da uğursuzluk getirdiği düşünülür. Bu vakitte en doğru olanın hiçbir iş yapmadan devamlı ibadet etmek olduğuna inanılır. Bu özelliklere sahip olduğuna inanılan akrep burcuyla sevgilinin saçları arasında klâsik Türk şiirinde sürekli bir ilgi kurulmuştur;

\section{Göreli zülfüni haddinde bildüm}

Ki akreb mâh-ı tâbân menzilidir

(Şeyhî, g. 51/4)

"Saçlarını yanaklarının üzerinde görünce parlak ayın akrep burcunda olduğunu anladım."

Sevgilinin güzellik unsurları aşağıdaki beyitte akrep burcu ve ay tutulması gibi iki ayrı doğa olayıyla ilişkilendirilmiştir;

Zülfün düninde haddüne hat geldi gûyiyâ

Vardukda bürc-i Akrebe tutıldı mâh-tâb

"Saçının gecesinde yüzüne ayva tüyleri geldi, sanki Akrep burcuna girildiğinde ay tutuldu."

Şair, sevgilinin üst yanağında saçıyla birleşen yerde bulunan ayva tüylerini akrep burcuyla bir araya gelen ahının dumanına benzetir.

Hat degüldür ol çıkup olan saçına muttasıl

Dûd-l âhumdur ki bürc-i 'akrebe peyvestedür (İshak Çelebi, g. 38/2)

"Yükselip saçınla bir araya gelen ayva tüyleri değildir; akrep burcuna kadar ulaşan ahımın dumanıdır."

Ay akrep burcu ilişkisini şiirlerinde çokça işleyen Ahmed Paşa, ay akrep burcundayken sefere çıkılamayacağını söyler. Ayın Akrep burcundayken seferin uğursuz sayılması âşı̆̆ın olduğu yerden, yani sevgilinin bulunduğu semtten uzaklaşamaması anlamına da gelir;

\footnotetext{
${ }^{29}$ Hafsanur Yıldırım, "Divan Şairlerine Göre Burçlar", Uluslararası Sosyal Araştırmalar Dergisi, C. 8, S. 41, Aralık 2015, s. 349.

${ }^{30}$ Kürşat Şamil Şahin, Sevgilinin Güzellik Unsurlarından Saç ve Saçın Âşık Üzerindeki Etkisi, Turkish Studies, Volume 6/3 Summer, 2011, s. 1863.
} 
Ey dil ruh u zülfün görüben terkimiz urma

Çıkma sefere k'oldu mehin menzili Akreb

(Ahmed Paşa, g. 10/4)

"Ey gönül! (Sevgilinin) yanak ve saçlarını bir arada görüp vazgeçme/yola koyulma; zira ay akrep burcundayken sefere çıkılmaz."

Gitmez kapindan ol ki göre zülf ü haddini

Akrebde olsa mâh degildir revâ sefer

(Ahmed Paşa, g. 73/3)

“Zülüf ve yanaklarını gören kapından ayrılmaz; nitekim ay akrepteyken sefere çıkmak uygun değildir."

çerâğ uyarmak: Topraktan ya da madenden, içine yağ konulup yan tarafindaki deliğe bir fitil takılarak yakmağa mahsus eski yă̆ kandillerine çeră̆ denilirdi. Çeră̆ aslında kandilin fitili olup parça bütün ilişkisinden dolayı sonraları kandil yerine kullanılmıştır. Çerağ Farsça bir kelime olup Türkçesi ise çıră̆ şeklindedir. Çerağ tarikat erkân ve ayinlerinde özel bir öneme sahiptir. Her türlü 1şıklandırma aracı tarikatlarda çerağ olarak adlandırılmıştır. Çerağ olarak adlandırılan ocak, mum, kandil, lamba vs. gibi aydınlatma araçlarının yakılması veya söndürülmesi icap ettiği zaman çırağı yak, çıră̆ı söndür denilmez çırağı uyandır, çırağı dinlendir denilirdi. Çerağ nefesle söndürülmez, elin hareketiyle dinlendirilirdi. Özellikle mutfakta yakılan mum ve lambaları uyandırmak için kullanılan kandillere de çerağ denilmiştir. Çerağın kudreti temsil ettiği kanaati de vardır. ${ }^{31}$ Osmanlı şairleri çerağ benzetme unsuru olarak çokça kullanmış, çerağ redifli şiirler yazmış, çerağla ilgili birçok tabir üretmiş, imgeler yakalamışlardır. Güzeli uykusundan uyandırmak çerağ yakmaya benzetilir;

Açmaz idi mihr ü meh hâb-l 'ademden gözlerin

Ger fürûg-ı tal'at-i hüsnün uyarmasa çerâg

(İshak Çelebi, g. 123/2)

“Güzel yüzünün nuru kandil yakmasaydı; güneş ve ay yokluk uykusundan gözlerini açmazdı.”

Çerâg uyarmadur gün gibi Nazmî

Bir ay yüzliyi uyhudan uyarmak

(Edirneli Nazmî, g. 3358/5)

"Nazmî! Bir ay yüzlüyü uykusundan uyandırmak; güneş gibi çırağı yakmaktır."

Dogupdur âfitâb-ı sâgar-l 'ışk

Çerâgın 'aklınun dinlendürigör

(Necâtî, g. 106 /2)

"Aşk kadehinin güneşi doğdu; artık çırağın fitilini söndür."

Çerâgı vâdi-i Eymen ocagından uyarursın

Eger pervâne-veş biryân idersen murg- idrâki

(Behiştî, g. 515/4)

"Eğer akıl kuşunu pervane gibi yandırırsan; çırağını Eymen ocağından yakmış (gibi) olursun."

\footnotetext{
${ }^{31}$ Mehmet Zeki Pakalın, age, C. I, s. 351-352; Ömer Tuğrul İnançer, “Osmanlı Tarihinde Sûfîlik Âyin ve Erkânları”, Osmanlı Toplumunda Tasavvuf ve Sufiler. (Ed. Ahmet Yaşar Ocak), Türk Tarih Kurumu, İstanbul, 2014, s. 344.
} 
Olınca çarha peyveste dilün âh-ı ciger-sûzı

Uyandurdı çerâg-ı âfitâb-l 'âlem-efrûzı

(Beyânî, g. 790/1)

"Gönlün ciğerleri yakan ahı gökyüzüne ulaştığında dünyayı aydınlatan güneş çırağını da yakmış oldu."

Uyanup çerâg-ı bahtum bana yâr olurdı tâli'

Dem-i vaslun âh iy mâh bana bir şeb olsa vâki' (Edirneli Nazmî, g. 3153/1)

"Ah, ey ay yüzlü! Bir gece vuslatına ulaşsaydım; bahtımın çırağı yanar, talih de bana yâr olurdu."

Şem’bir yalın ışıkdur ana pervâneleri

Kim çerâgın uyarur kimisi kurbân getürür

(Hamdullah Hamdi, g. 31/2)

"Mum yalın bir 1şıktır; pervanelerinin kimileri onun çırağını yakar, kimileri de ona kurban olur."

Aşağıdaki beyitte şehitlerin mezarlarında çıră̆ yakılma geleneğine işaret edilmiştir;

Gözlerün maktûlinün kabrinde nergisler bite

Ol şehîd-i 'ışk içün yer yer uyarmışlar çerâg

(Hayretî, g. 167/2)

"O aşk şehidi için yer yer çırağ yakmışlar; (oysaki) gözlerinin öldürdüklerinin mezarında nergisler biter/bitmeli."

Gönül ki şem'-i ruhundan uyardı çeşm-i çerâg

Fürûg-l şems ü kamerden n'ola iderse ferâg

(Helâkî, 80/1)

“Gönül, ay ve güneşin ışıltısından uzak durursa şaşılmamalı; (çünkü) o, gözünün nurunu yüzünün aydınlığından almıştır.”

Kandil fitillerinin yağlanmasında badem yağlarından yararlanıldığını aşağıdaki beyitten tespit edebiliriz;

Bâdâmdan ger olmasa rogan çerâgına

Dil çeşm-i yâri mahrem idinmezdi dâgına

(Faik Mahmud, g. 121/1)

"Bademlerden çırağlar için yağ elde edilmeseydi; gönül sevgilinin gözlerini yaralarına dost edinmezdi."

Mevlevîlikte uyandırmak; uyarmak, sâliki tasavvufî bir konuda irşat etmek anlamında da kullanılır. Uyanmak aynı zamanda âgâh olmak, anlamak, bilmek anlamina gelir. ${ }^{32}$

elleri başa koyup dualar etmek: Dua edilirken yapılan bedensel hareketler duanın bir parçası sayılır. Ayakta durma, diz çökme, eğilme, secde etme, başını eğme, elleri gökyüzüne doğru kaldırma, iki yana açma, kavuşturma, kenetleme, gözleri yukarıya dikme, elleri birbirine vurma, göğse veya alna vurma, ayakların çıplak veya giyinik, başın açık veya örtülü olması, vücudun bir yere yönelmesi gibi hâller çeşitli

32 Abdulbâki Gölpınarlı, Mevlevî Adâb ve Erkânı, Yeni Matbaa, İstanbul, 1963, s. 44. 
dinî çevrelerde dua esnasında görülen farklı davranışlardır. ${ }^{33}$ Elleri başa koymak, elleri göğe doğru kaldırmak birçok dinde karşılaşılan dua etme şekilleridir. İslâmda yaygın ve tabii dua vaziyeti diz çökerek elleri yukarı kaldırmak ve Allah'a övgü ve dualar etmek şeklindedir. Elleri göğe kaldırarak dua etmek aynı zamanda büyük bir şaşkınlığın, hayranlığın da ifadesidir. Klasik Türk edebiyatı şairleri bu dua şeklini yeri geldiğinde memduhunu övmek, sevgiliye olan bağlılıklarını ifade etmek için şiirlerinde bir metafor olarak kullanırlar.

\section{Sensin ol mahzen-i devlet ki varup hıdmetüne}

Ellerin başa koyup etdi du'ālar hātem

(İshak Çelebi, k. 6/11)

"Devletin mahzeni sensin; mühür senin hizmetine gelip ellerini başına koyup dualar etti."

Beyitte mühür memduhun övgüsünü yapmak için ellerini başına koyup memduhuna dualar eden birine benzetilmiştir. Osmanlıda mühürler büyük öneme sahip olup değişik şekillerde özenle süslenerek yapılmaktaydı. Mühürlerin rahatça kâğıtlara basılabilmesi için üst kısımlarına elle tutulabilecek bölümler yapılırdı. İşte mührün üzerindeki bu bölüm beyitte duaya kaldırılan ellere benzetilmiştir. Ellerin başa kaldırılması dua esnasında ellerin omuz hizasından daha yükseğe kaldırılmasıdır. İçten ve heyecanla yapılan dualar esnasında kişi ellerini yükseklere kaldırır. Ayrıca bu dua şekli bir hayret ifadesi olarak da görülür. Aşağıdaki beyitte bu dua şekline ait hususiyetler açıkça görülmektedir;

Ser-i 'alemde celâle degül görüp boyun

Elini başa koyup dedi yâr içün Allâh

(Emrî: Divan: g. 491/2)

"(Hilâl) bayrağın tepesinde boyunun yeterince heybetli olmadığını görünce ellerini başa koyarak sevgili için “Allah!” dedi./diye (dua etti.)”

hâme başın kesmek: Eskiden kalem olarak kamış divitler kullanılırdı. Bu kalemler boğumlu olup içleri eğridir. İçinde $n a ̂ l$ denen eğri saçaklar da bulunur. Kamış kalemin ortasındaki ince uzun lif şeklindeki bu saçakların ilk açımda çıkartılması gerekir. Kalemin içi yazılacak birçok hadiseyle doludur. Kalemin ucu çatala benzer olup iki dillidir. Kalemler bir süre kullanıldıktan sonra dili kesilir. Kalem dili kesildikçe düzgün yazmaya başlar. Ancak yine de aynı yazı ölçüsünü yakalayabilmek maharet ister. Ucunda biriken mürekkep ile yaş dolu gözü andırır. ${ }^{34}$ Sürekli kara mürekkep içinde oluşu itibariyle de kalem ile âşık arasında benzetme ilgisi kurulur.

Şair de bu ilgilerden hareketle sevgilinin aşkından dolayı zayıf düşüp artık gözyaşı dökemeyen âşığın kalem gibi başının kesilmesini ister.

Hâme-sıfat başını kes ol ki tarîk-l 'ışkda

'Âşı-ı ten-nizâr olup dîde-i eşk-bârı yok

(İshak Çelebi, g. 135/4)

"Mademki aşk yolunda zayıf düşmüş âşığın gözyaşı dökmüyor; başını kalem gibi kes."

33 Osman Cilac1, "Dua", TDVIA, C. 9, 1994, s. 529.

${ }^{34}$ Muhiddin Serin, Hat Sanatı ve Meşhur Hattatlar, Kubbealtı Neşriyatı, İstanbul, 1999, s. 282-284. 
Ko beni zâr olayın zülfün ucında niçe bir

Başumun kat'ina el uzadasın hâme miyem

(Adnî, g. 60/2)

"Beni bırak da saçının ucunda biraz inleyeyim; ben kalem miyim ki başımın kesilmesi niyetiyle el uzatıorsun."

Aceb mi hâme-i Âgâh olursa şûh-rakam

Ki tîg-ı ebrû-yı hûbân ile tırâş itdüm (Âgâh, g. 254/5)

“Âgâh'ın kalemi kıvrak ve güzel yazarsa buna şaşılır mı; keman kaşlı güzellerin oklarıyla (kalemimi) tıraş ettim.”

Şevk-i la'lün eşk-i çeşmüm rengini al eyledi

Hâme-i zülfün hayâli cismümi nâl eyledi

(İbn-i Kemâl, g. 401/1)

"La'l (gibi dudaklarına) duyduğum şevk gözyaşlarımın rengini kırmızıya çevirdi. Kalem gibi saçlarının hayâli bedenimi nal gibi eğdi."

Yazının güzelliği açısından kamış kalemlerin doğru şekilde açılması diğer bir ifadeyle kesilmesi son derece önemlidir. Bu iş yetenek ve ustalık ister. Öncelikle kalem sol avucun içine yatırılarak başparmak bükümü miktarınca aşağı ucuna doğru ince tarafından badem şeklinde kesilir. Kamışın boyuna paralel olarak birkaç santimetre uzunluğunda düz bir hat hâlinde kalem çatlatılırdı, bu iki yakaya ayrılma işine "şakk-i kalem" denirdi. ${ }^{35}$ Âgâh kalem çatlatılırken çıkan ses üzerine hüsnü talil yapmıştır;

Sadâ-yı hande gelür şakk-ı hâmeden Âgâh

Yazarsa kâtib-i a'mâl eger zarâfetümi

“Âgâh! Amel kâtibi zarafetimi yazarsa kalem çatlatılırken kahkaha sesi çıkar."

Dil hûn şod ez-cefâ-yı to ammâ ne-gûyemeş

Ger ser reved çü hâme şeved sîneem dü şak

(Münirî, fg 89/3)

"Başım kalem gibi kesilse, göğsüm ikiye yarılsa da eziyetinden gönlümün kanla dolduğunu söyleyemem."

Güzel koksun diye eskiden mürekkebin içine misk, abir, anber gibi kokular katılırmış. Bu ilgiden hareketle kalem, anber saçıcı özelliğinden dolayı sevgilinin misk kokulu saçına benzetilir;

Kâkülün vasfinda hâmem hatt-ı 'anber-bû döker

Dişlerün nazmında çeşmüm dem-be-dem lü 'lû döker

(Behiştî, g. 145/1)

"Saçlarını tasvir ederken kalemim anber kokulu yazar; dişlerini nazmederken gözlerim sürekli inciler döker."

penbeye sarılmış ayva: Eskiden elma, ayva, armut, üzüm, mısır gibi bazı sebze ve meyveler çürümelerini önlemek, soğuktan korumak için asılarak, serilerek, saman içine konularak veya pamuğa sarılarak saklanırdı. Kışın bu sebze ve meyveler

${ }^{35}$ Mutlu Melis Özgeriş, "XVIII. Yüzyıl Divan Şiirinde Hat Malzemeleri”, Uluslararası Türkçe Edebiyat Kültür Eğitim Dergisi, 2014, s. 172. 
taze taze yemek ya da hamilelere istediklerinde vermek üzere saklandıkları yerlerden çıkarılırdı. ${ }^{36} \mathrm{Bu}$ uygulamalar yerini soğuk hava depolarına, derin donduruculara bırakmış olsa da günümüzde de sürdürülmektedir.

Aşağıdaki beyitte de bulutu pamuğa benzeten şair bu âdetle ilgili benzetmeler yapmıştır;

Mihr ayvasını kat kat penbeye sardı sehâb

Postın urındı eginine bulutdan çarh-ı pîr

(Mesîhî, k. 11/2)

"Bulut, güneş ayvasını kat kat pamuğa sardı; yaşlı gökyüzü buluttan postunu sirtına sard1."

Sîb-i zekânun derdi ile zerd olup ölmiş

Sararsa bihe penbe 'aceb mi yed-i kudret

(Emrî, Mk. 40)

"Ayva, elmaya benzeyen çenenin kahrından sararıp ölmüş; kudret eli ona pamuk sararsa şaşılır mı?”

Penbeye sarllmış ayvadur nigâra sunmaga

Gözlerüm yaşı içinde çihre-i zerdüm benüm

(İshak Çelebi, g. 189/3)

"Gözyaşlarım içindeki sararmış çehrem; sevgiliye sunulmak üzere pamuğa sarılmış bir ayvadır."

Sanasan penbe ile saklanur bir tâze âbîdür

Nigârâ gabgabun üzre senün sîb-i zenahdânun

(Necâtî, g. 325/6)

"Sevgili! Zannedersin ki, gabgabın üstünde elmaya benzeyen çenen, pamuk içinde muhafaza edilen taze bir ayvadır."

Pamuğun kullanım alanı günümüzde olduğu gibi eskiden de çok geniş olup pamuk sadece meyve ve sebzeleri soğuktan korumak için kullanılmamıştır. Divanlar pamuğun kullanım şekli ve amacını gösteren beyit örnekleriyle doludur. Şairler yeni hayal ve imge arayışlarında pamuğu bir araç olarak değerlendirmişlerdir. Aşağıda pamuğun kullanım alanlarından birkaç örnek verilmiştir.

Hastelikden şöyle tenhâyam bu gurbet-hânede

Penbe ile agzuma su damzırur teb-hâleler

"Bu gurbet diyarında hastalıkta bile öyle yalnızım ki; dudaklarımdaki uçuklar pamukla ağzıma su damlatıyor."

Sinemde olan dâglarun penbesin alma

Pejmürde-zemîn eyleme ol lâle-sitânı

(Ahmed Yârî, g. 813/2)

"Bedenimdeki yaraların pamuklarını alma; o lale bahçesini tarumar etme."

Felek hıfz eylesün penbe içinde gevher-i zâtın

Ola zıll-i hümâyûnında dil-şâd-ı şeh-i 'Adlî

(Antepli Aynî, t. 410/7)

${ }^{36}$ Ahmet Talat Onay, age, s. 108. 
"Pamuk içinde saklasın zamane zatının cevherini; (felek) Şah Adlî’nin devletinin gölgesinde olmanın sevincini yaşasın."

Bahâr oldı açıldı gonca-lebler sahn-ı gülzâra

Güle yir yok meger yapışduram penbeyle dîvâra～(Bursalı Rahmî, g. 206/1)

"Bahar geldi gonca dudaklılar gül bahçelerine yayıldı; lakin pamukla duvara yapıştırmak için güle yer kalmadı."

rişte bağlatmak: Sitma hastalığının tedavisi için geçmişte kullanılan bir yöntemdir. İnanışa göre ergenlik çağına gelmemiş bir kızın eğirdiği ipliğe efsun okunup birkaç düğüm atılır ve sitma hastalığına yakalanmış kimsenin boynuna rişte-i teb denilen bu iplik bağlanırsa hasta şifa bulurdu. Birtakım kocakarı ilaçlarıyla tedavisi mümkün olmayan sıtma hastalığı için -halk bunlara papaz hummâsı, gâvur hummâsı" adlarını vermiştir- Müslümanlar, Rum ve Ermeni papazlarına; Hristiyanlar da Müslüman hocalara ve şeyhlere başvurarak iplik bağlatır ve okuturlardı. Sitma ipliği yalnız boyna değil bileklere ve topuklara da bağlanırdı. ${ }^{37}$

Sînemde gussa-i ser-i zülfün gürûh gürûh

Boynumda rişte-i teb-i hicrân girih girih

(Necâtî, g. 524/2)

"Göğsümde zülfünün ucunun gamı bölük bölük; ayrılık sıtmasının ipliği boynumda düğüm düğüm.”

Lerzende görse havfun ile teb tutar sanur

Baglar şihâb gerden-i gerdûna rîsmân

(Bâkî, k. 1/22)

"Kayan yıldız korkundan titrediğini görse, sıtmaya yakalandığını sanarak dünyanın boynuna sıtma ipliği bağlar."

Aşağıdaki beyitte de ayrılık derdi çeken âşık derdine derman arayışı içindeyken rişte bağlatmayı düşünmektedir;

Teb-i hecri ulaşdı ben garîbe

Neceyki rişte baglatmak hatîbe

(İshak Çelebi, ş. 1/81)

"Ayrılığının humması benim gibi bir garibe bulaştı. Hatibe ip bağlatmak nasıl olur?"

Muska yazdırmak da sıtmadan kurtulmanın yollarından biri kabul edilirdi. Bu muskalar badem üzerine yazılıp yenildiği gibi kâğıda yazılan muskaların da suda ezilip bu suyun içilmesiyle şifa elde edileceğine inanılırdı. ${ }^{38}$

Hummâ-yı 'ışka nüsha yüri kâr eylemez

Ey bana nüsha yazan anun iç suyını ez

(Zâtî, s. 25)

"Ey bana muska yazan! Onu ez, suyunu (sen) iç. Var git yoluna! Aşk hummasına muska kâr etmez."

\footnotetext{
${ }^{37}$ Ahmet Talat Onay, age, s. 380-381.

38 Emine Yeniterzi, "Divan Şiirinde Sağlık ve Hastalıklarla İlgili Bazı Hususlar", Selçuk Üniversitesi Sosyal Bilimler Enstitüsü Dergisi, 1998, s. 97.
} 
Tahirü'l-Mevlevî badem muskası geleneğini Mevlâna’ya kadar götürerek, Mevlevî şeyhlerinin üç tane bâdemin üzerine ezân, ezîn ve pesîn kelimelerini yazarak, sırasıyla günde bir tane sıtma hastasına yedirildiğini ifade eder. Badem üzerine yazılan muskalar yenilir, kâğıda yazılanların ise suyu içilir. Bu uygulamayla hastanın şifa bulacağına inanılırdı. ${ }^{39}$

Nüsha yazdursa 'aceb olmaya bâdâm üzre

Teb-i hicrâna 'ilâc eylemek ister hâtem

"Mühür badem üzerine yazı yazdırırsa şaşılmasın; ayrılık sıtmasına deva bulmak ister."

Vasf-ı çeşmün tan degül yazsam marîz-i 'aşk iken

Zahmet-i tebden yazarlar çünki bâdâm üstine

(Mostarlı Ziyâî, g.415/2)

“Aşk hastasıyken senin gözlerinin vasıflarını yazsam şaşılmamalıdır; çünkü sıtma hastaları için de bademin üzerine yazı yazılır."

semer doldurmak: Semer taşıdıkları yükün sırtlarına zarar vermemesi için at, katır, eşek, deve gibi yük taşıyan hayvanların sırtına konulur. Semer yapılırken ağaç iskelet üzerindeki deri veya keçe arasına dolgu malzemesi olarak kamış otları doldurulur. $^{40}$

Var semer toldur dedüm gâyetde ol har bunladı

Dedi degmen kâyilin arkamdagı pâlânuma

(İshak Çelebi, k. 14/21)

"Git semer doldur." dedim, o eşek çok sıkıldı. "Bana dokunmayın, arkamdaki palanıma razıyım." dedi."

İshak Çelebi’nin aşık oyununu konu alan kasidesinden alınan yukarıdaki beyitte şair, aşık oyununda sırası gelen sofuya seslenerek "Git semer doldur." demiştir. Semer doldurmaktan kasıt semer kılıfının içerisine kamışların doldurulmasıdır. Semere kamış doldurma işi semer yapımının en kolay aşamasıdır. Âşık, eşek olarak nitelendirdiği kaba sofuya 'git semer doldur' derken 'git bir işe yara, sen başka bir işe yaramazsın, senin elinden ancak bu iş gelir' demek istemektedir. Ayrıca kaba sofu doldurduğu semerden sonra palan yerine bir semer sahibi olacak ve daha çok işe yarayacaktır. Günümüzde de Güney Anadolu'nun köylerinde elinden bir iş gelmeyenler için git semer doldur tabiri kullanılmaktadır.

Yenişehirli Avnî devlet memurluğundan kaçınmayı tavsiye ettiği Gedâ-yı Zamân adlı manzumesinde okuyucuya yapabilecekleri meslekleri sıralar; tavsiye ettiği meslekler arasında semerciliği de sayar;

Hammâl-i bâr-keş olamazsan semerci ol

Peynirci turşucı katayıfcı biberci ol (Yenişehirli Avnî, m.[Gedâ-yı Zamân] 26/2) biberci ol.

"Hamal olamayacaksan (en azından) semerci, peynirci, turşucu, kadayıfçı,

${ }^{39}$ Bilal Kemikli, "Divan Şiirinde Hastalık ve Tedavi”, Uludağ Üniversitesi Illahiyat Fakültesi Dergisi, C. 16 , S. 1,2007 , s. $28-29$.

${ }^{40} \mathrm{http}: / /$ www.sanatpenceresi.com/semer-ve-kaybolan-semercilik/ (18.01.2017) 
şeb-külâh: Mevlevîlikte sikke ve arakıyye başlıkları haricinde geceleri giyilen ve boyu sikkeye göre daha kısa ve kalıpsız, arakıyyeye göre ise daha uzun olan bir sikke çeşididir. Mevlevî âdâb ve erkânı gereği başa giyilen sikke, uyku dışında hiçbir zaman çıkarılamazdı. Gece yatarken ise sikke itina ile çıkarılır, kenarı öpülerek iskemleye konur, sonra da şeb-külâh veya arakıyye giyilirdi. Mevlevîlik tarikatına has bir giysi olan sikke, Mevlevîliğin sembollerinden birisidir. Ter emici anlamına gelen arakıyyeyi ise henüz çilesini bitirmemiş dedeler dergâhın içinde giydikleri gibi; şeyh bu başlığı çocuklara, muhib (Mevlevîlikteki ilk kademe) olan kadınlara tekbirleyip verirdi. ${ }^{41}$ Şeb-külâhlar dövme yünden tek katlı ve yekpare imal edilir ve daha çok bal renginde veya beyaz olurlard1. ${ }^{42}$

Bu gün bir mâh-ı nev gördüm geyer bir şeb-külâh egri

Şarâb-ı nâzı nûş etmiş yürür geh dogru gâh egri

(Ahmed Paşa, g. 331/1)

"Bugün şeb-külâh giymiş yeni ay (gibi bir güzel) gördüm; naz şarabını içmiş, bazen düz bazen eğri yürüyordu."

Gitdi 'imâme geydügi bir şeb-külâhdur

Sevdâ-yı 'ışkun eyledi mâhı felek-zede

(İshak Çelebi, g. 274/3)

“Aşkının sevdası/karalığı ayı felekzedeye çevirdi; sarığı gitti, giyebildiği gecelik külâhtır.”

Aşağıdaki beyitten şeb-külâhların üzerine sarık sarıldığı da anlaşılmaktadır;

San yandı pīr-i 'aşkun destâr-ı şeb-külâhı

Yâ dîd-ı âh-l 'âşık hûrşîd-i tâba vardı

(Âsaf, g. 985/4)

"Zannedersin ki aşk pirinin gecelik külâhının sarığı tutuştu ya da âşı̆̆ın ahının dumanı parlak güneşe ulaştı."

Esen rüzgârın kafalardaki gecelik külâhları savurması gibi bir manzarayla çok karşılaşıldığı aşağıdaki beyitten anlaşılmaktadır. Beyitte geçen günümüzde de kullanılan külâh kapmak deyimi de firsattan istifade etmek, dalavere ile emeline kavuşmak, göz açıklığı yapmak anlamlarına gelmektedir ${ }^{43}$;

Hevâdan eyle güzer gitme hâneden ey şem ‘

$O$ düzd her gice haylice şeb-külâh kapar

(Âsaf, g. 242/2)

"Ey mum! Esintiden sakın/isteğinden vazgeç evden gitme; o hırsız her gece epeyce gecelik külâh kapar.”

şem', mıkrâz: Eskiden kullanılan temel aydınlatma aracı mum'du. Sahip olduğu öneme ve yaygınlığa binaen mumun kullanımıyla ilgili çeşitli yardımcı aletler ortaya çıkmıştır. Bunların başlıcaları şamdan, mum külâhı, şamdan hokkası,

\footnotetext{
${ }^{41}$ Serdar Ösen, “Osmanlı Devleti’nde Mevlevî Olmayanların Sikke Giymesine Karşı Alınan Önlemler”, Tarih Kültür ve Sanat Araştırmaları Dergisi, vol. 2, no. 1, Karabük, 2013, s. 343-345.

42 Abdulbaki Gölpınarlı, Tasavvuftan Dilimize Geçen Deyimler ve Atasözleri, s. 313.

${ }^{43}$ Hasan Kaya, Âsaf Divanı, (Marmara Üniversitesi Türkiyat Araştırmaları Enstitüsü Yayımlanmamış Doktora Tezi), İstanbul, 2009, s. 176.
} 
şamdan pulu, mum damlalığı ve mıkrazdır. Eskiden kullanılan yağ mumlarının fitilleri uzadıkça ziyaları azalırdı. Hem uzayan fitilleri keserek mumun ziyasını artırmak ve düzeltmek hem de mumu söndürmek için mıkraz denilen mum makasları kullanılırdı. Mıkrazın makastan farkı üst tarafında bir haznesinin bulunmasıydı; kesilen fitil uçları yere düşmeyerek bu haznede kalırdı. Mıkrazın diğer bir türü olan iki kanadı hazneli mıkrazlarla mum söndürüleceği zaman fitil hazneler arasında sıkıştırılır, bu suretle alevin havayla teması kesilirdi. Eski dönemlerde günlük hayatın vazgeçilmez bir parçası olan mıkrazlar daima şamdanların yanında ve bir tepsi içinde bulundurulurdu. Muma yardımcı bir araç olan mıkraz, Osmanlı şairleri için de yeni hayal ve imgelere kapı aralayan bir araç olarak görülmüss, mum ile olan münasebeti dolayısıyla beyitlerde bir benzetme unsuru olarak yer almıştır. ${ }^{44}$

Olsa mıkrâz-ı belâ-bârî de çekmez başını

Şem'-i bezmün farkı yokdur 'âşılk-ı ser-bâzdan （Kâtib-Zâde Sâkıb, g. 434/4)

"Meclisteki mumun korkusuz âşıklardan fark1 yok; zira bela saçan makas da olsa başını çekmez."

Mıkrâz-l 'ışka Şem'î boyun ver nizâ'ı ko

'Ayb olur ehl-i diller arasinda 'arbede

(Şem'î, g. 147/6)

"Ey Şem'î! Lakırdıyı bırak aşk makasına boynunu uzat; gönül adamları arasında arbede ayıptır."

Fetîl-i şu'le-tâb-i râhı pây-i istikâmetle

Gönül kat' itdi çün mikrâze-i şem'-i şebistânı

(Sâmî, k. 2/11)

"Gönlün istikamet üzere olması, halvethanedeki mumun makasının yolumu aydınlatan kandilin fitilini kesmesi gibidir.”

Ziyâ'înün efendi boynın ur şevkin ziyâd eyle

Ziyâsı şem 'ün artukdur kesince boynını mikrâz ～(Mostarlı Ziyâî, g. 203/5)

"Efendi! Ziyâ̂i’nin boynunu vur, şevkini artır; nitekim makas mumun boynunu kestiğinde 1 şı̆̆ çoğalır."

Zebânum şem'-veş kat' eyledüm mikrâz-l samtıyla

Safâ ehline bir rûşen delîl ü reh-nümâ oldum

(Rahîmî, g. 193/4) oldum."

"Suskunluk makasıyla dilimi mum gibi kestim; gönül ehline 1 şı ve kılavuz

Şair nefsi terbiye etmek için büyük sıkıntılarla karşılaşılan dünya hayatında ölümü mum makasına benzetir ancak ölümün bile gönül derdini bitirmeyeceğini düşünür.

Dimeye derd-i dili yana gide şem' gibi

Keserse başını râh-ı belâda ger mıkrâz

(Sehî, g. 114/5)

"Makas bela/imtihan yolunda başını keserse, gönül derdi mum gibi yanıp biter diye düşünme."

\footnotetext{
${ }^{44}$ Osman Ünlü, "Klasik Türk Şiirinde Mum Makası: Mıkrâz”, Littera Turca, Volume:3, Issue: 1, Winter 2017, s. 323-324; Mehmet Zeki Pakalın, age, C. II, s. 581.
} 
Kimse ol şem'-i cihân-efrûza nâ-zîbâ demez

Şekl-i mıkrâz ile nefy edüp cemâlin lâ demez

(İshak Çelebi, g. 105/1)

"O dünyayı aydınlatan muma kimse çirkin demez; makasla güzel yüzünü kesip yok diyemez/inkâr edemez."

Şair beyitte kimsenin sevgilinin güzel yüzünü makasla kesip inkâr edemeyeceğini söylemektedir. Şair bunu söylerken eski bir âdete de telmihte bulunmaktadır.

şîrînlik (muskası): Âdet olduğu üzere eskiden sevilmeyi, beğenilmeyi, ilgi görmeyi isteyenler üfürükçülere şirinlik muskası yazdırır ve onu sürekli yanlarında taşırlardı. Bu muskanın eşref saatinde yazılması şart idi. ${ }^{45}$ Aşağıdaki beyitte bu âdete telmih vardir;

Rûyında la'li üzre hat-ı müşg-bâr-ı yâr

Şîrînlik yazar şeref-i âfitâbda

(Bâkî, g. 469/4)

"Yüzünde, la'l dudaklarının üzerindeki misk saçan ayva tüyleri; güneş en tepedeyken (eşref saatinde) şirinlik yazar."

Bâkî’nin yukarıdaki beytinde görüldüğü gibi şirinlik muskası misk ile birlikte beyitlerde zikredilir. Şirinlik muskalarına misk sürüldüğünde, ya da miskli mürekkeple yazıldığında muskanın tesirinin artacağına hedefteki kişinin sevgisinin, ilgisinin daha kolay kazanılacağına inanılırmış. ${ }^{46}$

Ol dehânı pisteye cânlar müsahhar olmaga

Hattı şîrînlik yazar müşk ile 'unnâb üstine

(Cafer Çelebi, s. 40)

"Canları o fıstık ağzın büyüsüne kaptırmak için, ayva tüyleri kiraz dudaklarının üzerine miskten şirinlik yazar.”

Hattın ki tılısm etti lebin dâ'iresine

Şîrînlik için müşg ile efsûn yazar ey dost

(Ahmed Paşa, g. 15/2)

"Ey dost! Ayva tüylerin dudaklarının çevresine büyü bıraktı; belli ki şirinlik niyetine miskle büyü yapar."

Şirinlik, tatlı anlamıyla beyitlerde tevriyeli kullanılarak sevgilinin dudaklarını çağrıştırır. Hat, saç, dudak, yaz-, kalem, şeker, tatlı, sihir gibi yazı ve tatlılık kavramıyla ilgili kelimeleri çevresinde toplayarak tenasübe zemin hazırlar.

Nüsha yazmaga kosun misk ile gül evrâkına

Şehd-i la'lün var iken n'eyler hatun şîrînligi

(Sehî, g. 278/3)

"Ayva tüylerin miskle gül yapraklarına muska yazmaktan vazgeçsin; la'l dudaklarının tatlılığı varken şirinlikle ne işi var."

Tatlu sözlerle dudagun her gören cândan sever

Ana şîrînlik yazupdur hattun ey cânum meger (Edirneli Nazmî: Türkî-i Basît: $55 / 37)$

\footnotetext{
45 Ahmet Talat Onay, age, s. 429.

${ }^{46}$ Hakan Yekbaş, "Klasik Türk Şiirinde Bazı Halk İnanışları", Fırat Üniversitesi Sosyal Bilimler Dergisi, C.

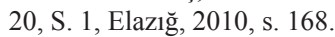


"Ey canım! Tatlı sözler söyleyen dudağını her gören candan seviyor; meğerse ayva tüylerin onun için şirinlik yazmış."

Şairler şiirlerini, şairliklerini övmek amacıyla yazdıklarını şirinlik muskasına benzetirler. İshak Çelebi şiirlerinin Rumeli güzelleri tarafından şirinlik (muskası) gibi kapışıldığını söyler.

Şi'ri İshâkun ne sihr eyler ki şîrînlik gibi

Birbirinden kapışurlar Rûmeli dilberleri

(İshak Çelebi, g. 337/7)

“İshak'ın şiirleri şirinlik gibi öyle bir büyü etkisi yapar ki, Rumeli dilberleri kapışırlar."

Nâme-i şi'r-i Revânîye yeter şîînlik

Hîç nâz ehline anun gibi tâmâr olmaz

(Revânî, g. 161/6)

"Revânî’nin şiirinin tınısı şirinlik olarak kâfidir; naz ehli için hiç onun gibi muska olur mu?"

Füsûn-ger hâmem ana yazmasa boyunca şîrînlük

Güzeller koynına girmezdi dîvân-ı şeker-pâşum

(Zâtî, g. 887/4)

"Sihirli kalemim sürekli ona şirinlik yazmasaydı; şeker saçan divanım güzellerin koynunu giremezdi."

Beyit örneklerinde görüldüğü gibi "şirinlik", şirinlik muskası yerine; "şirinlik yazmak" tabiri de, muska yazdırma yerine kullanılmıştır. Bu kelime ve tabir nüsha ve yazmak karinelerinden dolayı muska anlamını muhafaza etmekle birlikte beğenilmeyi, arzulanmayı, sevilmeyi karşılayan bir kelime ve deyim olma özelliği de kazanmışlardır.

şîșe-na'l, siper-âyine: Ok, eski Türklerde millî silah olarak kabul edilmektedir. Türk tarihinde ok, sadece bir savaş aracı olmakla kalmamış, okçuluk binicilikle birlikte beden kültürü anlayışının da öncüsü olmuştur. Okçuluk zevkli bir idman ve yarışma biçimine dönüştürülmüş bütün törenlerde en büyük yarışmaların vazgeçilmezi olmuştur. Yapılan idman ve yarışmalarda okun atıldığı mesafe ve oku hedefe isabet ettirebilme yeteneklerinin geliştirilmesi ve ölçülmesi amaçlanmıştır. Hedef okçuluğu, okçunun (kemankeş-kemânger-kemândâr, tîr-endâz-tîr-efgen, râmî, cündî[atlı okçular]) ve hedefin sabit ya da hareketli oluşuna göre değişik şekillerde gerçekleştirilmiştir. Özellikle at üzerindeyken hedef okçuluğu talimlerinde yüksek bir sütunun tepesine kabak yerleştirilir, okçu dörtnala giden atla sütunun yanından geçer, sonra da at üstünde dönüp hedefi vururdu. Bu ve benzeri talimler sadece savaşa hazırlık için değil okçuluk ve binicilikle ilgili becerilerin sergilenmesi için yapılırdı. Sabit veya hareketli iken kabak dışında toprak testi, içi pamuk çekirdeğiyle doldurulmuş testi, içi talaş doldurulmuş torba ${ }^{47}$, yastık, ayna, bardak, elma, taş, tunç ziller, altın top, fındık, külâh vb. hedef yapılırdı. Hedef okçuluğunun yanı sıra darp vurma adı verilen sert cisimleri

\footnotetext{
${ }^{47} 165$ ila 250 metre mesafeden "puta" denilen özel deri hedeflere ok atmaya puta atışı denirdi. Puta atışlarında, içi pamuk tohumu ve talaş doldurulmuş şekli kabaca armudu andıran yaklaşık insan gövdesi büyüklüğ̈̈nde deri hedefler kullanılırdı. Risalelerde, sepet șeklinde putalar da olduğundan bahsedilmektedir. Yüzeyinde hedef vazifesi gören renkli işaretler ve eteklerinde okun putaya çarpmasıyla ses çıkaran küçük ziller olurdu. (bk. http://www.avrasyasporbirligi.com/using/extensions/components/content-component/ article-category-list)
} 
delmeye yönelik talimler de yapılırdı. Darp vurma talimleri düşmanın zırhını delme amaçlı yapılmış olup bu talimlerde kompozit yaylar kullanılırdı. ${ }^{48}$ Klasik Türk şiirinde okçulukla ilgili birçok terim, tabir, kavram kullanılmış olup okçulukla ilgili tabirlerden hareketle oldukça orijinal imge ve hayaller beyitlerde sergilenmiştir. Geleneksel okçuluğun kapsamı ve klasik Türk şiirine yansıyan yönleri çeşitli çalışmalara ${ }^{49}$ konu olduğundan, çalışmamızın da amaç ve sınırlarını aştığından okçulukta hedef olarak seçilen şişse, na'l, siper ile ilgili beyitler örneklendirilmesiyle yetinilmiştir.

Okçulukla ilgili uygulama ve tabirler daha çok sevgilinin gözü ve bakışlarıyla ilişkilendirilerek beyitlere konu edilmiştir. Âşığın sinesi ve gönlü sevgilinin oklarının en belirgin hedefidir. Aşağıdaki beyitte sevgilinin mest bakışlarının hedefi âşığın gönlüyken, keman kaşlar hedef olarak gözlere içki kadehlerini göstermiştir. Şairin gönlü de hedef olamamaktan ötürü kırılmıştır;

Mestâne gözlerine sunup şişse gönlümü

Düşürdü tâkdan sıdı nâ-mihr-bân kaşın

(Ahmed Paşa: Divan: g. 165/9)

"Merhametsiz kaşların sarhoş gözlerine kadeh sunmakla gönlümü taktan düşürdü, kırdı."

Şair, usta bir okçuya benzettiği sevgilisinin yan bakışlarının nala benzeyen hilâli ve güneş şişesini delip geçtiğini söyler. Aşağıdaki beyitten eskiden ok atma talimlerinde at nalı ve delikli şişelerin veya bardakların hedef olarak kullanıldığını anlayabiliriz. Bu talimlerde esas hüner şişeyi kırmadan oku şişenin içinden geçirebilmekti, yani şişeyi delmekti. Bu talimlerden kalma okla delinmiş şişeler ile içine ok saplanmış şişeler bugün de müzelerimizde sergilenmektedir. ${ }^{50}$

Geçer âhum okı karşu felekün şîşelerin

Atıcılar deler ol resme ki san'atla zücâc

(Mesîhî, g. 25/5)

"Ahımın okları feleğin şişelerine geçer/girer; bu yöntemle atıcılar hünerle camları delerler."

Gamzen begüm ok atmada ehl-i hüner geçer

Na'l-i hilâli şî̧se-i mihri deler geçer

(İshak Çelebi, g. 55/1)

"Beyim! Gamzen ok atmada hüner sahibi olarak bilinir; (nitekim okların) nala benzeyen hilâli, güneş şişesini deler geçer."

Nice tîr-endâz-ı muhkem-şastdur ol ebrû-kemân

Sehm-i kahr ile olur sad-pâre bu dil şî̧sesi

(Âsaf, g. 1048/2)

"O keman kaşlı nasıl da soğukkanlı (zihgîre hâkim) okçudur, bu gönül şişesi kahrının dehşetiyle yüz parça olur."

Şişeler sadece ok atışlarında değil taş atışlarında da hedef olarak kullanılır;

\footnotetext{
48 (e. t. 18.01.2017)

49 İ. Hakkı Aksoyak, "Divan Şiirinde Okçuluk Terimleri”, Türklük Bilimi Araştırmaları, S. 1, Sivas, 1995, s. 81-94; İsmail Fazıl Aynacıoğlu, Ok Meydanı ve Okçuluk Tarihi, Vakıflar Genel Müdürlüğü Yayını, yer ve tarih yok; Atıf Kahraman, Osmanlı Devletinde Spor, Kültür Bakanlığı Yay. Ankara, 1995; Ünsal Yücel, Türk Okçuluğu, AKM Yay. Ankara, 1999.

${ }^{50}$ M. Fatih Köksal, "Divan Şiirinde Okçuluk Terimleri”ne Ekler, Türklük Bilimi Araştırmaları, S. 10, s. 247.
} 
Urursun seng-i cevri gerçi dâyim şî̧̧e-i câna

Meded ey seng-dil ammâ hazer kll inkisârumdan ～(Ahmed Yârî, g. 499/3)

"Her ne kadar sürekli cevir taşlarını can şişesine vursan da, ey taş gönüllü merhamet et! Kirılmamdan kork."

Ko seng-i cevr ile sad pâre eyle şîşe-i kalbüm

Ki her bir pâresinde sûret-i 'aşkun 'ıyân olsun

(Ahmed Yârî, g. 557/6)

"Bırak da kalbimin şişesi cevir taşlarıyla yüz parça olsun; böylelikle aşkının sureti her bir parçasında aşikâr olsun."

Beyitlerde bir arada kullanılan siper* ve ayna yine bir okçuluk terimidir. Ok atıcılarının talim yerindeki hedeflerinden biri de siper üzerine asılmış aynalar idi. Ancak bunlar bildiğimiz mânâda aynalar olmayıp, en sert yaylarla yapılan talimlerde kullanılan parlak demirden siperlerdi ${ }^{51}$ Okçular oklarını bu siperlere isabet ettirmek ve siperleri delmekle mükellefti.

Şol çarh-l felekde görinen şekl-i kevâkib

Âh oklarına âyînelerdür siper üzre

(İshak Çelebi, g. 236/5)

"Gökyüzünde görünen şu yıldız gibi şekiller; ah okları için siper üzerine konulmuş aynalardır."

Bâkî sipihr âhum okına siper tutar

Fark-ı felekde zâhir olan sanma hâledür

(Bâkî, g. 84/7)

"Bâkî! Gökyüzünün tepesinde görünenin hale olduğunu zannetme; gökyüzü ahımın oklarına siper tutuyor."

Kurs-ı meh ü hurşîdi siper itse de gerdûn

Cân kurtaramaz gamze-i nâvek-figenümden

(Âgâh, g. 280/7)

"Gökyüzü ay ve güneş küresini siper etse de ok saçan gamzelerimden kendisini kurtaramaz."

\section{Sonuç}

Sanatçılar yaşadıkları dönemden bağımsız düşünülemeyecekleri gibi edebiyat eserleri de ortaya konuldukları dönemden bağımsız değerlendirilemezler. Klasik Türk şiiri metinleri de geleneksel yapısından dolayı her ne kadar bazı çevrelerce toplumdan uzakmış gibi gösterilmeye çalışılsa da Osmanlı medeniyetinin, yüksek kültür birikiminin bir başka aynası konumundadırlar. Klasik Türk şiiri metinlerini meydana getiren çeşitli sosyal tabakalara mensup şairler yaşadıkları toplumun tarihini, geleneklerini, yaşayış biçimini eserlerine yansıtmışlardır. Bu metinler yazıldıkları dönemin tarihî olayları, toplum hayatı bilinmeden yorumlanamayacağı gibi edebî metinler de anlayıp yorumlanmadan devrin yaşayışı ve tarihî olaylarıyla ilgili satır

\footnotetext{
" Okçunun kabza elinin bileğine ve başparmağına tutturulan alete de siper denilmektedir. Bu alet ile daha kısa oklar, daha uzun çekişler ile atılabildiğinden menzil atışlarında kullanım alanı bulmuştur. Siper kullanılarak atılan kısa oklar daha hafiftir, daha yüksek esneme değerlerine sahiptir, daha yüksek hızlara ulaşır, daha uzağa uçar. http://www.avrasyasporbirligi.com/using/extensions/components/contentcomponent/article-category-list. (e.t. 06.12.2016)

${ }^{51}$ M. Fatih Köksal, agm., s. 237.
} 
araları okunamaz ve yorumlanamaz. Klasik Türk edebiyatı şairlerinin duygu, düşünce ve maksatlarını yepyeni imge ve hayallerle anlatabilmek için beslendikleri en önemli kaynaklardan birisi de toplum hayatıdır. Beyit ve dizeler Osmanlı toplum hayatına 1şık tutan pek çok bilgi ve malzemeyle doludur. Toplum hayatıyla ilgili hususlar tarih manzumelerinde, kasidelerin giriş bölümlerinde doğrudan ifade edilebilirken gazellerde sanatlı söyleyişlerle yoğrulmuştur. Şairler gazellerinde yaşadıkları toplumda gözlemlediklerini sembol ve benzetme unsurlarına dönüştürerek duygularını daha etkili anlatabilmeye çalışmışlardır. Çalışmada da toplum hayat unsurlarına dair örnekler özellikle gazellerden seçilmişlerdir. Farklı zamanlarda farklı coğrafyalarda yaşayan şairlerin aynı veya benzer unsurları gözlemlemiş olmaları ayrıca dikkate şayandır. Şairlerin gözlemlerindeki benzerlik ve ortaklık klasik Türk şiirindeki toplum hayatı unsurlarının tarih ve folklor açısından ne denli somut veriler ortaya koyduğunu da göstermektedir. Şairler toplum hayatında gözlemlediklerini farklı bakış açılarıyla hayal dünyalarında yeniden şekillendirmiş çeşitli söz ve anlam sanatlarıyla şiirlerine yansıtmış, toplum hayatıyla ilgili kavram ve tabirlerin semantik evrenlerini genişletmişlerdir.

\section{KAYNAKÇA}

AKPINAR, Şerife, Âgâh (Semerkandî-i Âmidî) Divan, Kültür ve Turizm Bakanlığ (e-kitap), http://ekitap.kulturturizm.gov.tr, (e.t. 25.11.2016)

ANDREWS, Walter, Şiirin Sesi, Toplumun Şarkısı, (çev.) Tansel Güney, İletişim Yayınları, İstanbul, 2012.

ARSLAN, Mehmet, Antepli Aynî Divanı, Kitabevi Yay. İstanbul, 2004.

AVŞAR, Ziya, Revanî Divanı, Kültür ve Turizm Bakanlığg (e-kitap) http://ekitap. kulturturizm.gov.tr/ (e.t. 22.07.2014)

AVŞAR, Ziya, Edirneli Nazmîve Türkî-i Basît, Sebat Ofset Matbaacılık, Konya, 2007.

AYDEMİ, Yaşar, Behiştî Dîvânı, Kültür ve Turizm Bakanlığı (e-kitap), http://ekitap. kulturturizm.gov.tr, (e.t. 05.10.2016)

BANARLI, Nihad Sami, Şiir ve Edebiyat Sohbetleri 2, Kubbealtı, İstanbul, 1982.

BAŞPINAR, Fatih, Beyânî Divan (İnceleme-Metin), Kültür ve Turizm Bakanlığ (e-kitap), http://ekitap.kulturturizm.gov.tr, (e.t. 25.11.2016)

BEKTAŞ, Ekrem, Muvakkit-zâde Muhammed Pertev Divanı, Kültür ve Turizm Bakanlığ1 (e-kitap), http://ekitap.kulturturizm.gov.tr, (e.t. 20.11.2016)

BİLGE, Murat, Günehkâr Divanı, (Kocaeli Üniversitesi Sosyal Bilimler Enstitüsü, Yüksek Lisans Tezi), Kocaeli, 2008.

BİRINCI, Nejat, Edebiyat Üzerine İncelemeler, Kitabevi, İstanbul, 2000.

CILACI, Osman, "Dua", TDVIA, c. 9, 1994, s. 529-530.

ÇAVUŞOĞLU, Mehmed - TANYERİ, M. Ali, Hayretî Dîvanı, İstanbul Üniversitesi Edebiyat Fakültesi Yayınları, İstanbul, 1981.

ÇAVUŞOĞLU, Mehmed, Helâkî Dîvanı, İstanbul Üniversitesi Edebiyat Fakültesi Yayınları, İstanbul, 1982.

ÇAVUŞOĞLU, Mehmed-TANYERİ, M. Ali, Zâtî Divanı, c. III, İstanbul Üniversitesi Edebiyat Fakültesi Yay. 1987. 
ÇELEBİOĞLU, Âmil, “Fuzûlî’nin Bir Beyti Üzerinde Bazı Düşünceler”, Osmanlı Araştırmaları VII-VIII, İstanbul, 1988, s. 199-210.

DİLÇİN, Cem, “Türk Kültürü Kaynağı Olarak Divan Şiiri”, Türk Dili, sa. 571, 1999, s. 618-626.

DOĞAN, M. Nur, Eski Şiirin Bahçesinde, Alternatif Yay., İstanbul, 2005.

ERDOĞAN, Mustafa, Kabûlî İbrahim Efendi, Hayatı, Edeb̂̂ Kişiliği ve Divanı (İnceleme-tenkitli metin-dizin), (Gazi Üniversitesi Sosyal Bilimler Enstitüsü, Yayımlanmamış Doktora Tezi), Ankara, 2008.

ERDOĞAN, Mustafa, Bursalı Rahmî ve Divanı, Kültür ve Turizm Bakanlığı, (e-kitap) http://ekitap.kulturturizm.gov.tr, (e.t. 24.11.2016)

ERSOY, Ersen, II. Bayezid Devri Şâirlerinden Münîrî Hayatı, Eserleri ve Dîvânı (İnceleme-Tenkitli Metin), Kültür ve Turizm Bakanlığ1, (e-kitap) http://ekitap. kulturturizm.gov.tr, (e.t. 04.11.2016)

ERÜNSAL, İsmail E, The Life and Works of Tâcî-zâde Ca'fer Çelebi, With A Critical Edition of His Dîvân, İstanbul Üniversitesi Edebiyat Fakültesi Yay. 1983.

FAYDA, Mustafa, "Atâ", TDVIAA, c. 4, İstanbul, s. 33.

GÖLPINARLI, Abdülbâki, Mevlevî Adâb ve Erkânı, Yeni Matbaa, İstanbul, 1963.

GÖLPINARLI, Abdülbâki, Tasavvuftan Dilimize Geçen Deyimler ve Atasözleri, İnk1lâp ve Aka Kitabevleri, İstanbul, 1977.

GÜRGENDERELİ, Müberra, Mostarlı Hasan Ziyâ'î Divanı, Kültür ve Turizm Bakanlığı, (e-kitap) http://ekitap.kulturturizm.gov.tr, (e.t. 08.12.2016)

INANÇER, Ömer Tuğrul, “Osmanlı Tarihihde Sûfîlik Âyin ve Erkânları”, Osmanlı Toplumunda Tasavvuf ve Sufiler, (Ed.) Ahmet Yaşar Ocak, Türk Tarih Kurumu, İstanbul, 2014.

İSEN, Mustafa, Usûlî Divanı. Akçağ Yayınları, Ankara, 1990.

İSEN, Mustafa, Şeyhî Divanı, Akçağ Yayınları, Ankara, 2013.

KAÇALİN, Mustafa S., Âĥे Dîvânı, Kültür ve Turizm Bakanlığı, (e-kitap) http:// ekitap.kulturturizm.gov.tr, (e.t. 24.11.2016)

KAÇAR, Mücahit, İbni Kemâl Dîvânı'nın İncelenmesi, (İstanbul Üniversitesi, Sosyal Bilimler Enstitüsü, Yayımlanmamış Doktora Tezi), İstanbul, 2010.

KARAHAN, Abdulkadir, Eski Türk Edebiyatı İncelemeleri, İstanbul Üniversitesi Edebiyat Fakültesi Yay. İstanbul, 1980.

KARAVELİĞLU, Murat A., Şem ’i Divan, Türkiye Yazma Eserler Kurumu Başkanlığ 1 Yayınları, 2014.

KARAYAZI, Nurgül, 17. Yüzyıl Şâiri Ahmed Yârî ve Dîvân'ı (Inceleme-Metin), (Marmara Üniversitesi, Türkiyat Araştırmaları Enstitüsü, Yayımlanmamış Doktora Tezi), İstanbul, 2012.

KAYA, Hasan, Âsaf Divanı, (Marmara Üniversitesi, Türkiyat Araştırmaları Enstitüsü, Yayımlanmamış Doktora Tezi), İstanbul, 2009.

KEKLIK, Murat, Üsküplü Ishak Çelebi: Divan [Metin-Çeviri-AçıklamalarDizin], Kırgızistan-Türkiye Manas Üniversitesi, Sosyal Bilimler Enstitüsü, Yayımlanmamış Doktora Tezi), Bişkek, 2014.

KEMİKLİ, Bilal, "Divan Şiirinde Hastalık ve Tedavi”, Uludă̆ Üniversitesi Illâhiyat Fakültesi Dergisi, c. 16, sa. 1, 2007, s. 19-36. 
KIRBIYIK, Mehmet, Kâtib-zâde Sâkıb Dîvânı, Kültür ve Turizm Bakanlığı, (e-kitap) http://ekitap.kulturturizm.gov.tr, (e.t. 16.10.2016)

KOÇAK, Fatma, Fâik Mahmud ve Dîvânı, (Gazi Üniversitesi, Sosyal Bilimler Enstitüsü, Yayımlanmamış Yüksek Lisans Tezi), Ankara, 2006.

KÖKSAL, M. Fatih, "Divan Şiirinde Okçuluk Terimleri”ne Ekler, Türklük Bilimi Araştırmalarl, sa. 10, s. 235-254.

KUFACI, Osman, Adnî Divanı ve Adnî Divanında Benzetmeler, (İstanbul Üniversitesi, Sosyal Bilimler Enstitüsü, Yayımlanmamış Yüksek Lisans Tezi), İstanbul, 2006.

KURTOĞLU, Orhan "Klasik Türk Şiirinde Saçı Geleneği”, Millî Folklor, sa. 81, 2009, s. 88-99.

KUTLAR, Fatma Sabiha, Arpaemîni-zâde Mustafa Sâmî Dîvânı, Kültür ve Turizm Bakanlığ1, (e-kitap) http://ekitap.kulturturizm.gov.tr, (e.t. 16.10.2016)

KÜÇÜK, Sabahattin, Bâkî Divanı Tenkitli Basım, TDK Yayınları, Ankara, 1986.

MACİT, Muhsin, Nedîm Divanı, Akçağ Yayınları, Ankara, 1997.

MENGİ, Mine, Mesîhî Dîvânı, Atatürk Kültür Merkezi Yayınları, Ankara, 1995.

MERMER, Ahmet, Kütahyalı Rahîmî ve Dîvânı, Sahhaflar Kitap Sarayı, İstanbul, 2004.

ONAY, Ahmet Talat, Eski Türk Edebiyatında Mazmunlar ve İzahı, (Haz. Cemal Kurnaz), TDV Yayınları, Ankara, 1993.

ÖSEN, Serdar, “Osmanlı Devleti'nde Mevlevî Olmayanların Sikke Giymesine Karşı Alınan Önlemler”, Tarih Kültür ve Sanat Araştırmaları Dergisi, vol. 2, no. 1, March, Karabük, 2013, s. 342-352.

ÖZGERIŞ, Mutlu Melis, XVIII. Yüzy1l Divan Şiirinde Hat Malzemeleri, Uluslararası Türkçe Edebiyat Kültür Eğitim Dergisi, 2014, s. 167-193.

ÖZKAN, Ömer, Divan Şiirinin Penceresinden Osmanlı Toplum Hayatı, Kitabevi Yayınları, İstanbul, 2007.

ÖZYILDIRIM, Ali Emre, Hamdullah Hamdî Divanı, Kültür ve Turizm Bakanlığg, (e-kitap) http://ekitap.kulturturizm.gov.tr, (e.t. 26.11.2016).

PAKALIN, M. Zeki, Osmanlı Tarih Deyimleri ve Terimleri Sözlüğ̈̈, c. I, II, III, MEB Yayınları, İstanbul, 2004.

SARAÇ, M. A. Yekta, Emrî Dîvânı, Kültür ve Turizm Bakanlığı, (e-kitap) http:// ekitap.kulturturizm.gov.tr, (e.t.16.01.2017)

SEFERCIOĞLU, Mustafa Nejat, "Divan Şiirinin Gerçek Hayatla Bağlantısı”, Türkler Ansiklopedisi, c.11, Yeni Türkiye Yay. Ankara, 2002, s. 664-681.

SERIN, Muhiddin, Hat Sanatı ve Meşhur Hattatlar, Kubbealtı Neşriyatı, İstanbul, 1999.

ŞAHİN, Esma, Klâsik Türk Şiirinde Pâleheng ve Bâkî'nin Pâleheng Konulu Bir Gazeli. Turkish Studies, Volume 7/3 Summer, Ankara, 2012, s. 2383-2392.

ŞAHİN, Kürşat Şamil, "Sevgilinin Güzellik Unsurlarından Saç ve Saçın Âşık Üzerindeki Etkisi”, Turkish Studies, Volume 6/3 Summer, 2011, s. 1863.

ŞEMSEDDIN SAMİ, Kâmûs-i Türkî, Kapı Yayınları, İstanbul, 2004, s. 356, 954.

ŞEN, Fatma Meliha, "Eski Türk Edebiyatında Sosyal Hayat Çalışmaları" Türkiye Araştırmaları Literatür Dergisi, c. 5, sa. 9, 2007, s. 467-506. 
ŞENTÜRK, A. Atillâ, "Klâsik Osmanlı Edebiyatı Işı̆̆ında Eski Âdetler ve Günlük Hayattan Sahneler", Türk Dili, sa. 495, 1993, s. 175-188.

ŞENTÜRK, Ahmet Atillâ, "Klasik Osmanlı Edebiyatında Tipler”, Osmanlı Araştırmaları XV, İstanbul, 1995, s. 1-91.

ŞENTÜRK, Ahmet Atillâ, "Manzum Metinler Işı̆̆ında Bir Kalender Dervişinin Profili”, Turkish Studies, Volume 10/8 Spring, 2015, s. 141-220.

TARLAN, Ali Nihad, Zâtî Divanı, C I, İstanbul Üniversitesi Fen-Edebiyat Fakültesi Yayınlar1, İstanbul 1967.

TARLAN Ali Nihad, Zâtî Divanı, C II, İstanbul Üniversitesi Fen-Edebiyat Fakültesi Yayınlar1, İstanbul 1970.

TARLAN, Ali Nihat, Ahmed Paşa Divanı, Akçağ Yayınevi, Ankara, 1992.

TARLAN, Ali Nihat, Necatî Beg Divanı, İstanbul: MEB Yayınları, 1992.

TİETZE, Andreas, Tarihi ve Etimolojik Türkiye Türkçesi Lugatı, C I, Simurg, İstanbulWien, 2002.

TULUM, Mertol, 17. Yüzyıl Türkçesi ve Söz Varlı̆̆ı, TDK Yay. Ankara, 2011.

TULUM, Mertol, TANYERi, M. A., Nev'î Divanı, İstanbul Üniversitesi Edebiyat Fakültesi Yayınları, İstanbul, 1977.

TURAN, Lokman, Yenişehirli Avnî Bey Divanı'nın Tahlili (Tenkitli Metin), Encümen-i Şuara ve Batı Tesirinde Gelişen Türk Edebiyatına Geçiş, (Atatürk Ünv. Yayımlanmamıș Doktora Tezi) Erzurum, 1998.

UZ, Özkan, Sabri Divanı, (Yüzüncü Yıl Üniversitesi, Sosyal Bilimler Enstitüsü Yayımlanmamış Doktora Tezi), Van, 2009.

UZUN, Süreyya, Üsküdarlı Aşkî Divanı Tenkitli Metin, Nesre Çeviri ve 16. yy. Osmanlı Hayatının Divandaki Yansımaları, (İstanbul Üniversitesi Sosyal Bilimler Enstitüsü Yüksek Lisans Tezi), İstanbul, 2011.

ÜNLÜ, Osman, "Klasik Türk Şiirinde Mum Makası: Mıkrâz”, Littera Turca, vol.3, issue: 1, Winter 2017, s. 321-329.

ÜST, Sibel, Edirneli Nazmî Dîvânı (Inceleme-Metin), Kültür ve Turizm Bakanlığg1, (e-kitap), http://ekitap.kulturturizm.gov.tr, (e.t. 05.01.2017)

YAVUZ, Hilmi, “Divan Şiiri, Simgeci Bir Şiir mi?”, Osmanlı Divan Şiiri Üzerine Metinler, (Haz. Mehmet Kalpakl1), İstanbul, YKY, 1999, s. 261.

YAZICI, Gülgün Erişen, Edirneli Kâmî ve Dîvânı, Kültür ve Turizm Bakanlığı, (e-kitap) http://ekitap.kulturturizm.gov.tr, (e.t. 21.12.2016)

YEKBAŞ, Hakan, Sehî Bey Divanı, Kitabevi Yay. İstanbul, 2010.

YEKBAŞ, Hakan, "Klasik Türk Şiirinde Bazı Halk İnanışları", Fırat Üniversitesi Sosyal Bilimler Dergisi, c. 20, sa. 1, Elazığ, 2010, s. 155-184.

YENITERZİ Emine, "Divan Şiirinde Sağlık ve Hastalıklarla İlgili Bazı Hususlar", Selçuk Üniversitesi Sosyal Bilimler Enstitüsü Dergisi, 1998, s.87-103.

YILDIRIM, Hafsanur, "Divan Şairlerine Göre Burçlar", Uluslararası Sosyal Araştırmalar Dergisi, c. 8, sa. 41, Aralık 2015, s. 340-353.

YILDIZ, Ali, 18. Yüzyıl Şairlerinden Ferhad Paşa Divanı, (Marmara Üniversitesi, Türkiyat Araştırmaları Enstitüsü, Yayımlanmamış Yüksek Lisans Tezi), İstanbul, 2006. 
YILMAZ, Ozan, 16. Yüzyll Şârihlerinden Sûdî-i Bosnevîve Şerh-i Gülistân' l, (Marmara Üniversitesi Türkiyat Araştırmaları Enstitüsü Yayımlamamış Doktora Tezi), İstanbul, 2008.

YÜCEL, Ünsal, Türk Okçuluğu, Atatürk Kültür Merkezi Başkanlığı Yay., Ankara, 1999.

ZÜLFE, Ömer, Şiirin İzinde Sözün Gölgesinde, Bilge Kültür Sanat Yayınları, İstanbul, 2001.

http://www.avrasyasporbirligi.com/using/extensions/components/content-component/ article-category-list (e.t. 18.01.2017)

http://www.sanatpenceresi.com/semer-ve-kaybolan-semercilik/ (e. t. 18.01.2017) 
